\title{
The Lessons of TPP and the Future of Labor Chapters in Trade Agreements
}

Alvaro Santos

Georgetown University Law Center, asantos@law.georgetown.edu

This paper can be downloaded free of charge from:

https://scholarship.law.georgetown.edu/facpub/2093

https://ssrn.com/abstract=3245894

The Lessons of TPP and the Future of Labor Chapters in Trade Agreements, in Megaregulation Contested: Global Economic Ordering After TPP (Benedict Kingsbury, et al., eds., Oxford University Press forthcoming).

This open-access article is brought to you by the Georgetown Law Library. Posted with permission of the author. Follow this and additional works at: https://scholarship.law.georgetown.edu/facpub

Part of the International Law Commons, and the International Trade Law Commons 


\title{
THE LESSONS OF TPP AND THE FUTURE OF LABOR CHAPTERS IN TRADE AGREEMENTS
}

\author{
Alvaro Santos* \\ [Forthcoming in MEgaregulation CONTESTED: Global ECONOMIC ORDERING AFTER TPP (Benedict \\ Kingsbury, et al., eds., Oxford University Press, 2018)]
}

\begin{abstract}
The agenda to link labor standards to trade agreements, in the hopes of improving working conditions in developing countries and preventing unfair labor competition for workers in rich countries, reached its culmination in TPP. Beginning with NAFTA and over a span of twenty-five years, labor standards became fully included in trade agreements and their violation subject to trade sanctions as means of enforcement. Thus, proponents of TPP offered it as the "gold standard" of globalization. This chapter argues that the debate about TPP, and the US labor movement's opposition to it, made clear that this was not a story of success but of disenchantment. Unions in the US criticized TPP's labor chapter for not going far enough, substantially and procedurally. But they also turned the focus to other chapters of TPP that may be just as or more important to workers in the US than the labor chapter: investment, rules of origin, procurement and currency manipulation. These areas have become the new frontier for labor advocates in trade agreements and they highlight the need to rebalance the treatment of capital and labor.

The chapter argues that a significant, though overlooked achievement of TPP, was to encourage several TPP parties to enact domestic labor reforms using labor side agreements and US pressure. More than any ideal labor chapter, it was these domestic reforms that held the most promise for improving working conditions in Vietnam and Mexico. The US withdrawal of TPP has set those reforms back. Opposition to TPP has also made clear that the expected losses from trade in the form of job loss and wage decline will not be made palatable in the absence of effective safety nets and compensatory mechanisms at the domestic level. In fact, international trade reputation will continue to suffer and opposition to it harden without them. To the extent that the debate about TPP was a referendum about liberal globalization as we know it, opposition to TPP in the US has given a resounding no. A pressing question is whether there is an alternative to the nationalist retrenchment embraced by the Trump administration. The revival of TPP without the US, unfortunately, does not seem to chart a different path.
\end{abstract}

\footnotetext{
* Professor of Law and Director of the Center for the Advancement of the Rule of Law in the Americas (CAROLA), Georgetown Law; Affiliate Professor at the Centro de Investigación y Docencia Económicas (CIDE), Mexico City. I would like to thank Adelle Blackett, Dan Brinks, Karen Engle, Cindy Estlund, Willy Forbath, James K. Galbraith, Rob Howse, and Benedict Kingsbury for comments and suggestions. I am grateful to Mario Osorio for excellent research assistance and to Thomas Streinz, Paul Mertenskötter and Rachel Jones for superb editorial support.
} 


\section{Contents}

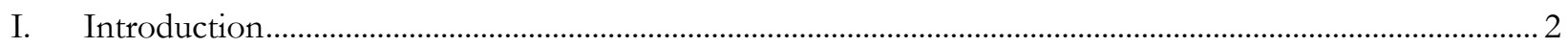

II. TPP: From Gold Standard to Lead Letter................................................................................................. 4

III. The Status of Trade and Labor Linkage—from NAFTA to TPP ............................................................ 6

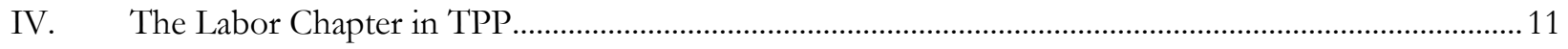

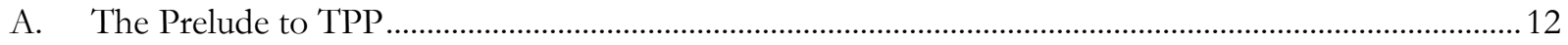

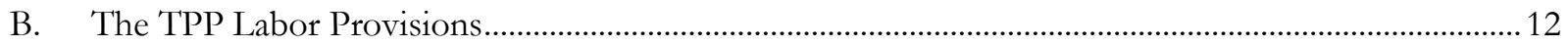

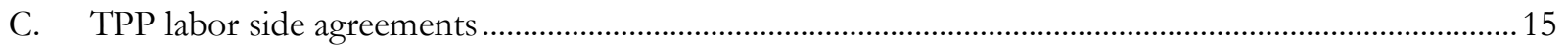

D. Roadblocks ahead in enforcing labor standards ....................................................................................2 21

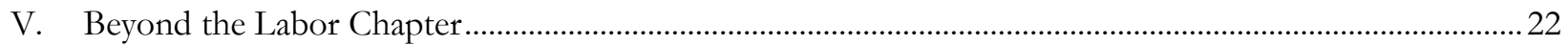

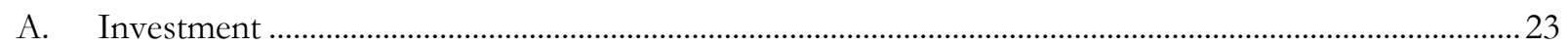

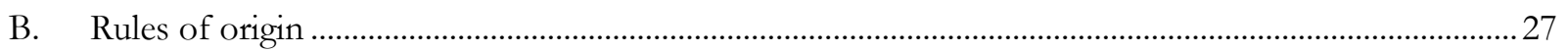

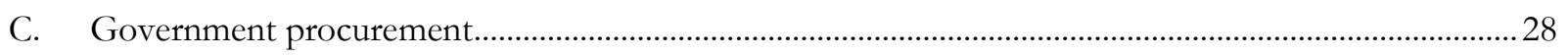

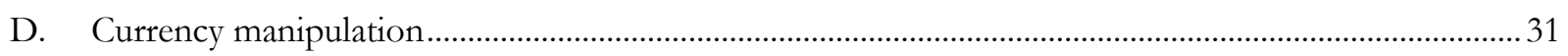

VI. The Pains from Trade and Domestic Compensatory Mechanisms ........................................................ 33

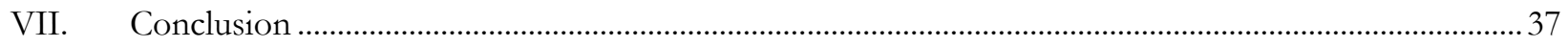




\section{Introduction}

One important lesson to learn after the failure of the original Trans-Pacific Partnership (TPP) is that the enforcement of labor rights through trade sanctions in a preferential trade agreement like TPP—desirable as it may be-will not address some of the most critical concerns in the global economy for working people in both rich and poor countries. Although there was mounting opposition to trade agreements in the US, as it was visible during the 2015-2016 presidential campaigns, it took the Leave vote in the UK's Brexit referendum and the election of Donald Trump to the US presidency to demonstrate the seriousness and magnitude of that opposition.

Concerns with the trade liberalization agenda include stagnant or declining wages; loss of well-paid, stable, and secure jobs in industries like manufacturing; increasing income inequality between top and low earners; and declining ability of workers to organize and bargain for better terms of employment. Some of these concerns have been voiced in nationalist and xenophobic rhetoric, blaming immigrants for the economic ills of the country. But beyond inflammatory scapegoating, international trade has figured prominently as a reason for national economic malaise.

From this perspective, it seems illusory to pretend that including a labor chapter in TPP could have assuaged workers and middle-class families hurting from economic decline. The original TPP contained—and the successor Comprehensive and Progressive Trans Pacific Partnership (CPTPP) keeps fully intact—a labor chapter that seemed the most advanced of any preferential trade agreement so far. However, unions in the US and other TPP countries opposed it, alleging that it did not go far enough. Labor stakeholders in the US argued that their proposals were not duly considered or incorporated in the text of the agreement. They also raised concerns about the negotiating process and the lack of effective enforcement mechanisms.

Moreover, even if an ideal labor chapter with better-defined obligations and effective enforcement mechanisms could have been agreed upon, the question remains as to whether such a chapter would be sufficient to address concerns about job losses and declining wages in the industrialized world, given the vast wage and other labor cost differentials between rich and poor countries. A labor chapter incorporating internationally recognized labor standards establishes only a minimum floor for preventing the most outrageous labor practices. Such a chapter could be understood as safeguarding basic human rights but seems insufficient, however, to address broader worries about jobs and wage levels in the current form of trade liberalization.

Thus, it may be that the most important steps for retooling the global economic regime to address the concerns of labor and the working class are not about perfecting labor chapters in trade agreements. Rather, those steps may be toward rebalancing key levers for distribution of power and wealth at international and domestic levels. At the international level, labor advocates may gain by focusing on other legal regimes, such as investment, rules of origin, government procurement, currency manipulation, and tax. At the 
domestic level, labor groups may certainly gain by focusing on labor-related initiatives, like minimum wage and collective bargaining. But they may have much to gain, too, by focusing on background policy regimes that greatly affect workers such as: establishing safety nets traditionally associated with good, stable jobs such as health insurance, maternity leave, and childcare; investment in human capital such as education and training; and compensatory mechanisms such as unemployment insurance, income support, and job placement programs.

At the domestic level, states have largely failed to include robust safety nets and compensatory mechanisms that could deal with the dislocation and losses predicted by trade theory. At the international level, the structure of the global economic regime, as articulated by the trade, investment, and tax regimes, has produced a profound asymmetry between capital and labor in their ability to move beyond borders. It has also created a profound imbalance between the ability of low-skilled and high-skilled labor to reap the benefits of globalization. Furthermore, by creating regulatory competition, many states have diminished their ability to tax and to impose conditions on capital. Domestically, many states have reduced social safety nets precisely at the moment when the losers of globalization may have needed them the most.

Finally, the results of the 2016 US presidential election pose a challenge to the form that economic globalization has taken, and this challenge may present an opportunity to recalibrate its outcomes. An important question is whether this rebalancing will necessarily disadvantage developing countries—as for instance, Trump's rhetoric seems to suggest in the case of NAFTA and Mexico-or, alternatively, whether this rebalancing of concessions also offers an opportunity for developing countries to increase their policy autonomy for heterodox development policies and rely less on TPP-like agreements as a strategy for growth.

The first part of this chapter describes the debate about TPP and the concerns about its distributive effects. The second part discusses the TPP labor chapter as the culmination of a progressive trajectory of linkage between trade and labor in trade agreements. It analyzes why the labor movement in the Unites States opposed the chapter, despite its being the most advanced labor chapter ever in a trade agreement. The third part suggests that a big lesson of TPP is that organized labor in industrialized countries seems to no longer believe in the idea that a labor chapter would 'level the playing field' and thus help avoid job losses. Labor opposition seems to suggest that the interests for organized labor reside well beyond the labor chapter and relate to other areas of trade agreements that may have a greater bearing on wage decline and job loss. The last part argues that changes in international agreements need to be complemented by domestic policies and safety nets that make the losses from globalization bearable and that allow people to take advantage of new market opportunities. The chapter concludes by arguing that the failure of the original TPP in the United States should invite us to rethink the architecture of international trade agreements, putting the question of effects on workers and wealth distribution front and center. The revival of TPP as the CPTPP should not veil these defects and the important criticism of the agreement as insensitive to these concerns. As the US 
conducts negotiations on NAFTA reform, we should heed these lessons, and no longer pretend that a new labor chapter could be the solution to concerns over wage stagnation and job losses.

\section{TPP: From Gold Standard to Lead Letter}

On 23 January 2017, on his first week day after inauguration, President Trump withdrew the United States from TPP. This departure fulfilled a campaign promise and put an end to the signature trade accomplishment of the Obama administration. ${ }^{2}$ It was a harbinger of a shift in the new administration's position towards international trade agreements. The US's exit was not a death blow to TPP, and the remaining parties resuscitated the agreement by suspending some significant provisions while keeping its overall model. ${ }^{3}$ Even so, the US's exit represents a formidable material and symbolic challenge.

The negotiation and signing of TPP spurred a heated debate in the United States about the benefits of free trade. A preferential trade agreement between twelve nations situated on both sides of the Pacific Ocean, TPP represented close to $40 \%$ of the world's GDP. Advocates of TPP, led by the Obama administration, advanced it as the 'gold standard' of free-trade agreements. They emphasized expected economic benefits in terms of growth and jobs as well as geo-political advantages, namely exerting influence in Asia in the face of China's increasing clout by 'writing the rules' of international trade.

Opponents (a group which eventually included all presidential candidates and a mix of civil society groups) criticized the agreement for its potential effects on job losses, lax environmental protections, and the centrality of corporate interests. Indeed, the most contentious aspect of TPP was its investment chapter, particularly its investor-state dispute settlement (ISDS) system. Opponents of TPP derided it as an infringement on US sovereignty because it bypassed national courts and made the government potentially liable if it passed social regulation-such as health, environmental, or consumer protection-that contravened investors' interests.

The potential economic benefits of TPP were highly contested and even optimistic studies deemed them to be relatively modest in terms of growth and job creation. Economists in the pro-TPP camp suggested that the agreement would increase annual real income in the United States by USD 131 billion or $0.5 \%$ of GDP by 2030 , and would have practically no effect on employment levels. ${ }^{4}$ Those against TPP

\footnotetext{
2 According to TPP, art 30.5, if not all signatories have ratified after 2 years of signature, then TPP can enter into force when at least 6 countries comprising $85 \%$ of GDP of original signatories have ratified. This effectively means that without the US, TPP can't enter into force since the US alone represents more than 50\% of GDP of original TPP signatories. TPP, art 30.5 .

3 On 10 November 2017, the ministers of Australia, Brunei Darussalam, Canada, Chile, Japan, Malaysia, Mexico, New Zealand, Peru, Singapore, and Vietnam announced that they had agreed on the 'core elements' of the Comprehensive and Progressive Agreement for Trans-Pacific Partnership. See Trans-Pacific Partnership Ministerial Statement (10 November 2017) <https://perma.cc/5P45-FCWC>.

${ }^{4}$ Peter A Petri and Michael G Plummer, 'The Economic Effects of the Trans-Pacific Partnership: New Estimates' (2016) PIIE Working Paper No 16-2 <https://perma.cc/WUK2-BE4S>; see also Robert Z Lawrence and Tyler Moran, 'Adjustment and Income Distribution Impacts of the Trans-Pacific Partnership' (2016) PIIE Working Paper No 16-5
} 
predicted that it would inflict a negative GDP loss of $0.54 \%$ in the US by 2025 and that the growth effects across all countries would be negligible or negative. In terms of employment, critics contended that TPP would produce a loss of about 450,000 jobs in the US and 771,000 overall by $2025 .{ }^{5}$ As one might suspect, these estimates vary according to the models used, and there is disagreement about which are the best models to run these estimates. ${ }^{6}$

But even if there were gains, the distributional concerns remained serious. These were particularly worrisome because, judging from experience with previous trade agreements, the losers are hit hard and largely left to their own devices. The distributional consequences of trade policy can be quite dramatic. It is hard to think of another policy domain, like tax, where such redistribution would be palatable without a greater analysis of the beneficiaries' situation as well as the intended effect and use of the gains. ${ }^{7}$ Moreover, the existing compensatory mechanisms in the US, such as trade-adjustment policy, are notoriously limited, and the broader social safety nets (except for health), such as education, housing, and unemployment insurance, seem smaller and less accessible than they were before.

So, the debate about TPP in the United States was highly contentious, with even staunch proponents of liberal globalization raising concerns about the benefits of the agreement and its potential distributive consequences. ${ }^{8}$ It is important to remember that opposition to the original TPP and the type of liberal globalization it represented came not only from Trump, but also from the presidential candidates in the Democratic party. The fact that all the final candidates for the US presidency opposed TPP says something about the level of discontent in American society regarding job losses attributed to competition with imports or outsourcing and wage stagnation. ${ }^{9}$ This calls for analysis of how the original TPP assuaged (or not) its potentially negative effects on US workers and jobs. Traditionally, these concerns have been addressed through the labor chapters in trade agreements. The next section explores the question of whether or not TPP did, and does, enough to address labor concerns.

$<$ https://perma.cc/J46M-RMDH> (arguing that TPP 'will confer net benefits to households at all levels of income and will certainly not worsen income inequality').

${ }^{5}$ Jeronim Capaldo, Alex Izurieta and Jomo Kwame Sundaram, 'Trading Down: Unemployment, Inequality and Other Risks of the Trans-Pacific Partnership Agreement' (2016) Global Development and Environment Institute Working Paper No 16-01 <https://perma.cc/XUH7-HEZV> 17-18.

${ }^{6}$ See Dani Rodrik, 'The Trade Numbers Game' Project Syndicate (Cambridge 10 February 2016)

$<$ https://perma.cc/8QPL-VSEM> (analyzing and critiquing both models: 'The bottom line is that neither side's models generate numbers reliable enough on which a case for or against the TPP can be made. Just about the only thing we can say with some certainty is that there will be winners and losers. Perhaps the agreement will galvanize investment and knowledge flows across the Pacific, giving the world economy a much-needed boost. Perhaps not. But those who believe that this trade agreement, like previous ones, will provide lopsided benefits have ample reason to be concerned.')

${ }^{7}$ Dani Rodrik, The Globalization Paradox: Democracy and the Future of the World Economy (Norton, New York 2012) 55-61.

${ }^{8}$ See Lawrence Summers, 'Rescuing the Free-Trade Deals' Washington Post (Washington DC 14 June 2015)

$<$ https://perma.cc/ABP6-NNNK>.

9 Jacob Poushter, 'American Public, Foreign Policy Experts Sharply Disagree Over Involvement in Global Economy' Pew Research Center Fact Tank (28 October 2016) < https://perma.cc/M399-UQ7K>; Bruce Stokes, 'Republicans, Especially Trump Supporters, See Free Trade Deals as Bad for US' Pew Research Center Fact Tank (31 March 2016) $<$ https://perma.cc/LG28-CE44>. 


\section{The Status of Trade and Labor Linkage-from NAFTA to TPP}

The inclusion of labor standards in trade agreements has been a contentious and gradual process. Proposals to link labor standards to trade have often come from governments of rich countries who see it as a way to eliminate unfair competitive advantage from developing countries and to respond to concerns from organized labor about potential job losses. The conclusion of the North American Free Trade Agreement (NAFTA) is a good example. Facing opposition from organized labor to an agreement that President George H. Bush had signed, President Clinton proposed the inclusion of the side agreements on labor ${ }^{10}$ and the environment and thus managed to work out a compromise. ${ }^{11}$

Those agreements have been rightly criticized as ineffective for obliging countries only to their own domestic labor standards, rather than internationally accepted ones, and for lacking enforcement teeth. ${ }^{12}$ Despite these limitations, they helped build new alliances between labor groups across countries, and also revealed that labor conditions in the US, not only in Mexico, often left much to be desired. ${ }^{13}$ Thus, the NAFTA labor side agreement served to point out violations of labor standards and mobilize to address them in all NAFTA countries. Subsequent preferential trade agreements sought to improve on the deficiencies of the NAFTA and did so very gradually, attempting to include internationally recognized labor standards and to ramp up the enforcement mechanisms. ${ }^{14}$

At the multilateral level, at the first World Trade Organization (WTO) Ministerial Conference, held in Singapore in December 1996, President Clinton floated a proposal to include labor standards. The proposal was strongly rejected by governments of developing countries who insisted that trade and labor should be kept apart. ${ }^{15}$ The WTO was not the right institution, they argued, and labor concerns should be

\footnotetext{
10 See North American Agreement on Labor Cooperation (US, Canada, Mexico) (adopted 8-14 September 1993, entered into force 1 January 1994) 32 ILM 1499 [NAALC].

${ }^{11}$ See Marley Weiss, 'Two Steps Forward, One Step Back-Or Vice Versa: Labor Rights Under Free Trade Agreements from NAFTA, Through Jordan, via Chile, to Latin America, and Beyond' (2003) 37 U San Francisco L R 689, 701-02; see also Lance Compa, 'NAFTA's Labour Side Agreement Five Years On: Progress and Prospects for the NAALC' (1999) 7 Canadian Labour \& Employment L J 1, 2; Stephen F Diamond, 'Labor Rights in the Global Economy: A Case Study of the North American Free Trade Agreement' in Lance Compa and Stephen Diamond (eds), Human Rights, Labor Rights, And International Trade 199 (Penn Press, Philadelphia1996).

${ }^{12}$ Lance Compa, 'How to Make the Trans-Pacific Partnership Work for Workers and Communities' The Nation (14 January 2016) < https://perma.cc/U859-9V23>; Lance Compa, NAFTA's Labor Side Agreement and International Labor Solidarity' (2001) 33 Antipode 451, 460-61 (discussing why, despite the bureaucratic, 'soft law' nature of the NAALC's legal mechanism, critics from the left should seize it to advance their interests).

${ }^{13}$ Human Rights Watch, 'Trading Away Rights: The Unfulfilled Promise of NAFTA's Labor Side Agreement' (Report) (April 2001) Vol 13, No 2(B) < https://perma.cc/WKY9-DP4W> (reviewing the cases filed against Mexico and the United States).

${ }^{14}$ See Cathleen Cimino-Isaacs, 'Labor Standards in TPP' in Cathleen Cimino-Isaacs and Jeffrey J Schott (eds) TransPacific Partnership: An Assessment (Policy Analyses in International Economics, PIIE, Washinton 2016)

<https://perma.cc/HQM8-LGKV> (summarizing the differences in coverage of labor provisions in the FTAs of the United States, and how TPP has gone beyond other FTAs in labor standards); see also Weiss, 'Two Steps Forward, One Step Back' (analyzing the evolution of labor provision starting with the NAALC).

${ }^{15}$ Developing country members rejected including labor issues on the negotiating agenda, with concerns about how labor standards would undermine their economic development or be used by developed countries to protect labor-
} 
dealt with by the International Labor Organization (ILO). Race-to-the-bottom arguments-the idea that trading with countries relying on low labor standards would create pressure to decrease standards in rich countries—advanced by rich country governments and unions were received as protectionist plots in poor developing countries, which consider their low-cost labor a comparative advantage.

The linkage of trade and labor standards has many vectors, and rich government to poor government friction is only one of them. Unions in rich countries may also have a genuine interest in the working conditions of their fellow workers in poor countries. Moreover, workers and independent unions in poor countries are often interested in linking labor to trade agreements as a way to improve their standards and collective bargaining rights by acquiring another tool to use against their government and official unions. Similarly, unions in rich countries may have an interest in linking trade to labor standards not only out of solidarity with workers in poor countries, but also to add more leverage to the improvement of labor standards at home. So, interests align in various ways, and support or opposition depends on the context.

Since its inception, the linkage of trade and labor has been perceived as a channel through which workers in rich countries could avoid unfair competitive pressure and thus 'level the playing field'. ${ }^{16}$ Linking trade to labor standards would protect workers in rich countries from losing out to cheaper imports produced with low-cost labor or prevent their jobs from moving to poor countries where labor standards were routinely violated. At the very least, by increasing labor standards in poor countries, the argument went, those standards would prevent job losses in rich countries that resulted from unfair competition. ${ }^{17}$ However, it seems that even when labor standards are enforced—and they often are not, due to vast differences in labor costs - the goal of leveling the playing field has remained elusive.

It is not that labor standards don't belong in trade agreements. It is rather that they can't stop the competitive forces of labor cost differentials. Presenting them as a solution to the pressures on workers in rich countries may serve to legitimize the trade agreements in question but does little to counteract those pressures and is bound to disappoint. Labor standards, however, also have other goals. They can certainly be used to combat the worst forms of labor exploitation in developing countries. Workers and civil society groups in poor countries can use them as tools to organize, bargain for better conditions, and shame rogue

intensive industries. In the Ministerial Declaration, the ministers stated that they 'renew[ed their] commitment to the observance of internationally recognized core labour standards,' but reaffirmed 'The International Labour Organization (ILO) [as] the competent body to set and deal with these standards.' The Declaration also censured 'the use of labour standards for protectionist purposes,' and recognized 'that the comparative advantage of countries, particularly low-wage developing countries, must in no way be put into question.' See WTO Singapore Ministerial Declaration (13 December 1996) W'T/MIN(96)/DEC, 36 ILM 218.

${ }^{16}$ Kevin Kolben, 'The WTO Distraction' (2010) 21 Stanford L \& Policy Rev 461, 468 (tracing the connection between trade and unfair labor conditions to the Charter of the International Trade Organization); Kevin Kolben, 'A Development Approach to Trade and Labor Regimes’ (2010) 45 Wake Forest L Rev 355, 356-57 (referring to labor provisions being necessary to prevent a destructive race to the bottom).

${ }^{17}$ See Robert Howse, 'The World Trade Organization and the Protection of Workers' Rights' (1999) 3 J Small \& Emerging Business L 131, 132 (noting that free trade critics have argued that it is unfair for producers in developed countries to compete with imports from countries with low labor standards). 
corporate actors. Enforceable labor standards in trade agreements could be a useful tool in contexts where governments—and official union leadership—are complicit with corporate wrongdoing and enforcement of national regulation is ineffective. In this way, the linkage could be understood as part of a human rights agenda, with all the benefits and complications of the international human rights movement. ${ }^{18}$

Labor standards have also been included in rich countries' generalized system of preferences, a regime under which rich countries grant special, non-reciprocal tariff treatment to imports of poor countries. An explicit exception to the most-favored nation obligation in the WTO, this special treatment is subject to certain conditions determined by rich countries. ${ }^{19}$ In addition, a number of scholars have proposed that countries could impose trade restrictions on imports produced in violation of internationally recognized labor standards, invoking the exception of public morals contained in Article XX (a) of the WTO General Agreements on Tariffs and Trade (GATT). ${ }^{20}$ Some have even proposed that trade restrictions, in the form of discriminatory treatment, against imports of goods produced in violation of labor standards could be defended, arguing that such goods are not 'like' products under the analysis of the national treatment obligation. ${ }^{21}$ Even if those arguments became successful and labor standards were thus incorporated in the WTO regime - a big if - it seems unlikely that there would be significant effects on the competitive pressures referred to above. It is much more likely that they would be a useful tool to fight egregious violations of labor rights in particular sectors in poor countries.

It has also been noted that wages and working conditions in export industries are often better than in the rest of the country.22 This presents a difficulty since jobs in the export industries, even when substandard by international standards, may be more desirable for workers, relative to jobs in the internal market. At the same time, it may be easier to exert pressure on companies providing those jobs, precisely because they are connected to foreign markets and may be more vulnerable to consumer and workers' pressure in rich countries' markets. Export companies are also often connected to global supply chains where the ultimate

\footnotetext{
18 See Kevin Kolben, 'Labor Rights as Human Rights?' (2010) 50 VJIL 449 (arguing there are important points of convergence between human and labor rights discourses, but cautioning labor advocates from seeking to emulate the strategies of the human rights movement).

${ }_{19}$ The US Generalized System of Preferences (GSP) subjects eligibility to countries that have taken or are taking steps to afford internationally recognized worker rights, including: 1) the right of association; 2) the right to organize and bargain collectively; 3) a prohibition on the use of any form of forced or compulsory labor; 4) a minimum age for the employment of children, and a prohibition on the worst forms of child labor, and 5) acceptable conditions of work with respect to minimum wages, hours of work and occupational safety and health. In addition, GSP beneficiaries must implement any commitments made to eliminate the worst forms of child labor. See Trade Act of 1974 (19 USC 2012 ) s 2462(b)(2). See Vivian C Jones, 'Generalized System of Preferences (GSP): Overview and Issues for Congress' (2017) CRS Reports RL33663 < https://perma.cc/V5UQ-7BUX>

${ }^{20}$ See Robert Howse and Michael Trebilcock, The Regulation of International Trade (4 ${ }^{\text {th }}$ edn Routledge, New York 2013) 733-38; see also Howse 'The World Trade Organization and the Protection of Workers' Rights' 142-45.

${ }^{21}$ Howse and Trebilcock, The Regulation of International Trade 732.

${ }^{22}$ Kimberly Ann Elliott and Richard B Freeman, Can Labor Standards Improve Under Globalization? (PIIE, Washinton 2003) 127-39; see also Raymond Robertson and others, Globalization, Wages, and the Quality of Jobs (World Bank, 2009)

<https://perma.cc/N8T7-2Z8T> 6-9.
} 
buyer is an internationally recognized company with a brand to protect and an interest in ensuring that its brand is not tainted by a labor rights violations scandal. ${ }^{23}$

So, if TPP represents the apex in the trajectory of the linkage between trade and labor, its rejection by labor unions in the United States and in other industrialized countries seems to reflect deep skepticism about its effectiveness. It is indeed possible to see a gradual progression from NAFTA to TPP around two main axes: substantive rights and enforcement mechanisms. ${ }^{24}$ On the weak side of the spectrum, NAFTA committed partners to enforce their own domestic laws and its enforcement mechanisms were mainly toothless. ${ }^{25}$ On the stronger side of the spectrum, TPP refers to internationally recognized labor standards and provides for greater enforcement mechanisms, including the possibility of trade sanctions. ${ }^{26}$ If the labor chapter in TPP represents such progress, why did unions in the US and in several other TPP countries oppose it?27 I now turn to answer this question.

\footnotetext{
${ }^{23}$ Elliott and Freeman Can Labor Standards Improve Under Globalization? 50-56.

24 See Cimino-Isaacs 'Labor Standards in TPP'.

${ }^{25}$ See Compa, 'How to Make the Trans-Pacific Partnership Work for Workers and Communities' Compa, 'NAFTA's Labor Side Agreement and International Labor Solidarity'.

${ }^{26}$ See Cimino-Isaacs, 'Labor Standards in TPP'; Kevin Kolben, 'A New Model for Trade and Labor? The Trans-Pacific Partnership's Labor Chapter and Beyond' (2017) 49 NYU JILP 4, 1063 (maintaining that, while evolutionary rather than revolutionary, the TPP's labor chapter stands as a constructive and helpful progression from previous labor chapters).

${ }^{27}$ Letter from Richard L Trumka, AFL-CIO President, to Barak Obama, President of the US (8 June 2015)

<https://perma.cc/QA68-L67X>.
} 
US FTA Enforcement of Labor Standards: From Least to Most Stringent

\begin{tabular}{|c|c|c|c|c|c|}
\hline & NAFTA & $\begin{array}{c}\text { US-Chile FTA } \\
\text { US-Singapore FTA } \\
\text { US-Australia FTA } \\
\text { US-Morocco FTA } \\
\text { US-Bahrain FTA } \\
\text { CAFTA-DR } \\
\text { US-Oman FTA }\end{array}$ & $\begin{array}{c}\text { US- } \\
\text { Jordan } \\
\text { FTA }\end{array}$ & $\begin{array}{c}\text { Post May } 10 \\
\text { Agreement: } \\
\text { US-Peru FTA } \\
\text { US-Korea FTA } \\
\text { US-Colombia FTA } \\
\text { US-Panama FTA }\end{array}$ & TPP \\
\hline Year(s) of entry into force & 1994 & $\begin{array}{c}2004 \\
2004 \\
2005 \\
2006 \\
2006 \\
2006-09 \\
2009\end{array}$ & 2001 & $\begin{array}{l}2009 \\
2012 \\
2012 \\
2012\end{array}$ & - \\
\hline Labor provisions incorporated into the main agreement & $x$ & $\checkmark$ & $\checkmark$ & $\checkmark$ & $\checkmark$ \\
\hline A party shall not fail to enforce its own labor laws & $\checkmark$ & $\checkmark$ & $\checkmark$ & $\checkmark$ & $\checkmark$ \\
\hline \multicolumn{6}{|l|}{ Each party shall adopt and maintain the following rights (ILO Declaration): } \\
\hline \multirow{5}{*}{$\begin{array}{l}\text { Freedom of association } \\
\text { Right to collective bargaining } \\
\text { Elimination of all forms of forced or compulsory labor } \\
\text { Abolition of child labor and a prohibition on the worst forms of child labor } \\
\text { Elimination of discrimination in respect of employment and occupation }\end{array}$} & $x$ & $x$ & $x$ & $\checkmark$ & $\checkmark$ \\
\hline & $x$ & $x$ & $x$ & $\checkmark$ & $\checkmark$ \\
\hline & $x$ & $x$ & $x$ & $\checkmark$ & $\checkmark$ \\
\hline & $x$ & $x$ & $x$ & $\checkmark$ & $\checkmark$ \\
\hline & $x$ & $x$ & $x$ & $\checkmark$ & $\checkmark$ \\
\hline $\begin{array}{l}\text { Each party shall adopt and maintain acceptable conditions of work (minimum } \\
\text { wages, hours of work, and occupational safety and health) }\end{array}$ & $x$ & $x$ & $x$ & $x$ & $\checkmark$ \\
\hline Parties shall not derogate from labor rights in special trade or customs area & $\mathbf{x}$ & $x$ & $x$ & $x$ & $\checkmark$ \\
\hline Parties shall discourage the importation of goods produced by forced labor & $x$ & $x$ & $x$ & $x$ & $\checkmark$ \\
\hline \multicolumn{6}{|l|}{ Dispute settlement: } \\
\hline \multirow{3}{*}{$\begin{array}{l}\text { Recourse to the dispute settlement provisions of the main agreement } \\
\text { Recourse to dispute settlement, but only for failure to enforce labor laws } \\
\text { Separate dispute settlement, but only for failure to enforce occupational safety } \\
\text { and health, child labor, or minimum wage labor standards }\end{array}$} & $x$ & $x$ & $\checkmark$ & $\checkmark$ & $\checkmark$ \\
\hline & $x$ & $\checkmark$ & $x$ & $x$ & $x$ \\
\hline & $\checkmark$ & $x$ & $x$ & $x$ & $x$ \\
\hline \multicolumn{6}{|l|}{ Remedies: } \\
\hline \multirow{4}{*}{$\begin{array}{l}\text { Labor commitments subject to trade sanctions } \\
\text { Monetary assessment for labor commitments in lieu of suspension of benefits } \\
\text { Only a limited monetary penalty, to be used for labor initiatives } \\
\text { Upon failure to pay the monetary penalty, other steps to collect or secure } \\
\text { compliance may be taken, including suspension of tariff benefits }\end{array}$} & $x$ & $x$ & $\checkmark$ & $\checkmark$ & $\checkmark$ \\
\hline & $x$ & $x$ & $x$ & $\checkmark$ & $\checkmark$ \\
\hline & $\checkmark$ & $\checkmark$ & $x$ & $x$ & $x$ \\
\hline & $\checkmark$ & $\checkmark$ & $x$ & $\checkmark$ & $\checkmark$ \\
\hline
\end{tabular}




\section{The Labor Chapter in TPP}

To understand the labor movement dissatisfaction with the labor chapter we need to consider their own proposals and the extent to which they were incorporated. And just as importantly, we need to read the labor movement opposition to the TPP in light of the broader critiques of the effects of trade on labor, well beyond the labor chapter. This would suggest that, in the eyes of the labor movement, the real problem with TPP was not so much, or at least not entirely, the labor chapter. Or that even if the labor chapter had reflected the concerns of the labor movement in the US, there were other areas of TPP that raised greater concerns for their potentially negative effects on job losses.

Unions in the United States made concrete proposals during the negotiations, but they felt largely ignored. ${ }^{1}$ The final TPP chapter basically includes what had been gained in the US-Peru Trade Promotion Agreement of 2007, with some additions. The experience of the Peru-PTA baseline, however, had not been positive and unions had hoped to improve on it. ${ }^{2}$ So, judged against the unions' own proposals, the final text of the labor chapter fell significantly short, and unions did not want to legitimize it.

The labor chapter included bilateral labor side agreements between the US and Vietnam, Malaysia and Brunei. Unions in the US also deemed those agreements insufficient. An important lesson, however, is that a trade agreement like TPP can set in motion important labor law reforms in countries where the government had previously resisted them. Beyond the substantive rights of the labor chapter, and the design of its enforcement mechanisms, an overlooked aspect of TPP is that it set in motion significant domestic reforms and realigned the interests of domestic actors to support reform. These domestic legal and institutional changes, along with the entrance of new labor players who would defend them, may have been in the end even more important than a fully functional labor chapter. Thus, an important lesson of the failure of the original TPP is that there were also important costs of opposing TPP for improving conditions of labor in developing countries. The new CPTPP, without US participation, does not contain such labor side agreements and thus lifts this pressure from the countries who had already committed to enact reform.

\footnotetext{
${ }^{1}$ See American Federation of Labor and Congress of Industrial Organizations [AFL-CIO], Testimony Regarding the Proposed United States-Trans-Pacific Partnership Trade Agreement before the United States Trade Representative (25 January 2010) <https://perma.cc/PDB5-7RJW>.

${ }^{2}$ Citizens Trade Campaign, 'Oppose the Peru and Panama Free Trade Agreements' (2007)

$<$ https://perma.cc/LVM7-6F4K> (criticizing the Peru PTA for subordinating the enforcement of labor commitments to the Executive Branch and allowing panels to interpret the provisions of the ILO Declaration liberally); see Mark Barenberg, 'Labor Rights in the US-Peru Agreement: One Step Forward, Two Steps Back?' (2007) < https://perma.cc/2H5E-QNSM > (arguing that the PTA's enforcement mechanisms are weaker than those provided under US law).
} 


\section{A. The Prelude to TPP}

On 10 May 2007, the Bush Administration and Democratic Party leaders reached a compromise agreement for minimum labor standards in all pending free trade agreements (FTAs): Peru, Colombia, Panama, and South Korea. The agreement was called the 'New Trade Policy for America' and is commonly referred to as the 'May 10 agreement'. ${ }^{3}$ This compromise was effectively included in the USPeru FTA.

The 'May 10' template, encompassed in the US-Peru agreement labor chapter, included three important obligations for countries: 1) to 'adopt and maintain' in law and practice the five basic rights contained in the ILO Declaration on Fundamental Principals and Rights at Work, 2) to enforce those laws effectively and 3) to set up a dispute settlement system that could provide remedies to violations through fines and trade sanctions. ${ }^{4}$

\section{B. The TPP Labor Provisions}

During the TPP negotiating process, the US government promised an improvement over the USPeru trade agreement, so that the TPP labor chapter would offer a 'Peru-plus' deal. ${ }^{5}$ In the end, the new commitments included: 1) requiring parties to adopt laws concerning 'acceptable conditions of work with respect to minimum wages, hours of work and occupational safety and health, ${ }^{3} 2$ ) not to waive or derogate from 'minimum wage, hours of work, or occupational health and safety standards in export processing zones, ${ }^{17}$ 3) to discourage importation of goods or goods containing inputs made by forced labor, regardless of country of origin, ${ }^{8}$ and 4 ) the commitment that countries 'shall endeavor to encourage enterprises to voluntarily adopt corporate social responsibility initiatives. ${ }^{\prime 9}$

The USTR referred to these clauses as 'the high-water mark for labor protections in a trade agreement'. ${ }^{10}$ But unions and labor groups disagreed. The Labor Advisory Committee on Trade Negotiations and Trade Policy—representatives of unions and labor groups who make recommendations to the USTR in the course of negotiations-harshly criticized the core of the labor chapter as a 'mere

\footnotetext{
${ }^{3}$ See Office of the United States Trade Representative [USTR], 'Bipartisan Agreement on Trade Policy' (2007) $<$ https://perma.cc/JVW9-XLEB> 1-2.

${ }^{4}$ See Table above at 10. United States-Peru Trade Promotion Agreement (adopted 12 April 2006, entered into force 1 February 2009) <https://perma.cc/4EU6-CYGH> ch 17.

${ }^{5}$ See Minutes of Meeting, National Advisory Committee for Labor Provisions of US Free Trade Agreements (NAC) (United States Department of Labor, 27 September 2012) <https://perma.cc/WWJ4-TK7C>.

6 TPP, art 19.3.2.

7 ibid art 19.4 (b).

8 ibid art 19.6.

9 ibid art 19.7 .

${ }^{10}$ See USTR, 'TTP Labor Chapter Summary' (2016) < https://perma.cc/7XYY-D2AB> 8.
} 
copy' of the Peru model, which should not be considered a ceiling on labor rights. ${ }^{11}$ The Committee and other labor critics raised several criticisms:

1. Definitional clarity. The chapter, as the Peru template, fails to provide a clearly defined labor standard. It focuses on the 'ILO's 1998 Declaration of Fundamental Principles and Rights at Work, as opposed to the ILO Conventions and accompanying reports and recommendations, which do provide well-established standards.' Thus, the extent of the obligation remains uncertain. ${ }^{12}$

2. Low bar on working conditions. Although for the first time in a trade agreement, TPP requires parties to adopt laws concerning 'acceptable conditions of work with respect to minimum wages, hours of work, and occupational safety and health'-as opposed to simply requiring parties to enforce existing laws - it also determines that these obligations will be satisfied 'as determined by' each party. ${ }^{13}$ So, parties can set a very low bar in each of these matters and still comply with the obligation. ${ }^{14}$

3. Weak protection on forced labor. The chapter failed to prohibit trade in 'goods made with forced labor', requiring instead parties to 'discourage' it. ${ }^{15}$ This provision could be fulfilled with minimum effort as long as the state does something to discourage forced labor. Its elusiveness was captured by the AFL-CIO when it claimed that the state could comply with it by 'hanging a poster'. ${ }^{16}$

4. Limited protection against derogation from labor rights. Although the chapter includes a commitment 'not to waive or derogate from laws implementing acceptable working conditions' such as minimum wage, hours of work, and occupational health and safety, it only

${ }^{11}$ Labor Advisory Committee on Trade Negotiations and Trade Policy [LAC], 'Report on the Impacts of the TransPacific Partnership' (2015) <https://perma.cc/4JJ7-RQ9S> 65.

12 ibid; see also Human Rights Watch, 'A Way Forward for Workers' Rights in US Free Trade Accords' (2008) $<$ https://perma.cc/3WTE-EVGK> 8-9 (analyzing the ambiguity of the 'May 10' text and recommending that future text includes reference to 'rights ... as listed in the Declaration and defined in the ILO core conventions'); Human Rights Watch, 'The 2007 Trade Policy Template: Opportunities and Risks for Workers' Rights' (Backgrounder, 2007) <https://perma.cc/FYT4-V5QB>; For a debate regarding the advantages and drawbacks of labor standards as legal principles (ILO Declaration) or as legal rights (ILO Conventions), see Philip Alston, 'Core Human Rights and the Transformation of the International Labour Rights Regime' (2004) 15 EJIL 457; Brian A Langille, 'Core Labour Rights-The True Story (Reply to Alston)' (2005) 16 EJIL 409.

13 Article 19.3.2, footnote 5

14 AFL-CIO, 'A Gold Standard for Workers? The State of Labor Rights in Trans-Pacific Partnership Countries' (2016) < https://perma.cc/8BUR-3NE2> 5 (stating that a country that sets any minimum wage, provides long-hour shifts with no overtime pay, or makes workers obtain their own safety gear can still meet the standards of TPP). $15 \mathrm{ibid}$.

${ }^{16}$ LAC, 'Report on the Impacts of the Trans-Pacific Partnership' 66 (referring to the AFL-CIO's 'The State of Labor Rights in Trans-Pacific Partnership Countries'). 
applies to Export Processing Zones (EPZ). This leaves unprotected the vast majority of workers in TPP countries. ${ }^{17}$

5. Aspirational and vague language. Most of the additional text to the Peru template, 'relies on legally imprecise language like "may" and "endeavor to encourage". This language is hortatory and falls very short of establishing clear protections for workers in the TPP countries'. ${ }^{18}$

When analyzed more closely, it seems that the 'plus' parts of the agreement did not considerably improve the minimum floor of labor standards already there in its basic form. At first blush, the new obligation to adopt laws concerning minimum wages, working hours, and occupational safety and health seemed like an important addition. But leaving the content and satisfaction of these obligations to the signatories' determination, as opposed to an international standard drawn from ILO conventions, made them considerably less effective. Moreover, when the text included specific obligations, they were circumscribed to particular areas. Consider the commitment not to waive or derogate from existing standards regarding wages, hours, and health and safety in export processing zones. Was it not the whole idea of the agreement that labor standards would be enforced everywhere? And why prevent slippage only in certain zones? Was that an implicit recognition that standards could be watered down elsewhere without consequences?

Consider now the obligation to discourage imports of goods made with forced labor, regardless of origin. The prohibition against forced labor had been well-established in previous PTAs, including the Peru PTA, and countries could impose trade sanctions against a breaching country. So, why include a commitment to 'discourage' the imports of such goods? Was the existing commitment otherwise not enough? What seemed truly innovative in this commitment was that it extended to goods or goods produced with inputs made with forced labor, regardless of the source country. This meant that the import restriction applied to goods made with inputs produced by forced labor in non-TPP countries. But the commitment 'to discourage' imports seemed so weak as to mean very little in practice. So, the 'plus' parts of the agreement did not seem to add much value after all. A sympathetic reading would grant that the additions sought to hold the floor of minimum labor standards recognized by the ILO, even though this floor was already included in previous agreements.

Critics also raised a serious concern about procedural delays. Article 19.9 did not impose a timeline on the US Department of Labor and its counterparts for advancing labor complaint submissions. ${ }^{19}$ Nor did it require parties to move to the next stage in the dispute settlement process when

\footnotetext{
17 ibid.

18 ibid.

19 AFL-CIO 'A Gold Standard for Workers?' 4 (citing as precedent a 2012 labor complaint filed against Honduras pursuant to the CAFTA-DR: <https://perma.cc/WQP6-GUEG>).
} 
an earlier stage proves ineffective. ${ }^{20}$ In the view of the AFL-CIO, the United States' track record in pursuing and discouraging labor rights violations was not reassuring. They pointed out that the United States had never imposed trade sanctions or even a fine in response to labor violations. ${ }^{21}$ Thus, the failure of the text to ensure effective dispute resolution to avert procedural stalling as well as the history of unsatisfactory enforcement in trade agreements gave the AFL-CIO little confidence that labor rights would be enforced under TPP.

\section{TPP labor side agreements}

One important feature of the labor chapter were the special commitments made by Brunei, Malaysia, and Vietnam in the form of labor consistency plans. ${ }^{22}$ During the negotiations, USTR obtained important concessions from these countries, long suspected of widespread labor standard violations, to improve their domestic labor standards. ${ }^{23}$ These countries signed bilateral agreements with the US which conditioned their ability to partake of TPP benefits to reforming their own domestic labor laws. They agreed to adopt and enforce international labor standards, and to open themselves to monitoring mechanisms. After the US withdrawal of TPP these countries no longer have the same market incentives or diplomatic pressure to proceed with their domestic labor law reforms. The new CPTTP does not include these obligations.

The agreement with Vietnam concerns the biggest market of the three, and thus is the one where more pressure for reform and higher scrutiny would be expected. ${ }^{24}$ The United States / Vietnam Plan for the Enhancement of Trade and Labor Relations ${ }^{25}$ stipulated a series of legal reforms Vietnam needed to implement as part of its membership in TPP and, for the most part, prior to TPP's date of entry into force. The plan included changes to incorporate and make effective the rights to freedom of association and collective bargaining, union autonomy, the right to strike, non-discrimination, prohibition of forced labor, and prevention of child labor, among others. ${ }^{26}$ The Plan also included 'institutional reforms and

\footnotetext{
20 ibid 3 (citing as precedent a 2008 labor complaint filed against Guatemala pursuant to the CAFTA-DR:< https://perma.cc/A2E3-R36G>).

${ }^{21}$ It should be noted, however, that a number of labor complaints have been filed with reports being issued by the US Department of Labor under the following agreements: Bahrain Free Trade Agreement, Dominican RepublicCentral America Free Trade Agreement (CAFTA-DR), Colombia \& Peru Trade Promotion Agreement, and North American Free Trade Agreement (NAFTA). See USTR, Labor, 'Bilateral and Regional Trade Agreements' $<$ https://perma.cc/ME8S-7Z97>

${ }^{22}$ See United States-Brunei Labor Consistency Plan (adopted November 2015) < https://perma.cc/HV2Q-QKJV>; United States-Malaysia Labor Consistency Plan (adopted November 2015) <https://perma.cc/4B8Z-FWNY>; United States-Vietnam Plan for the Enhancement of Trade and Labor Relations (adopted 4 February 2016) $<$ https://perma.cc/5NAP-429B $>$ [VLCP].

${ }^{23}$ See Judd Cohen, 'Falling Short for Labor: Why the Trans-Pacific Partnership Does Not Do Enough for Workers' Rights, and Evaluating Better Options' (2017) 49 Case Western Reserve J Int'l L 275, 285-88.

24 Asian Development Bank, Basic Statistics 2017 (ADB, April 2017) <https://perma.cc/TH43-7FH4> 6.

${ }^{25}$ See VLCP.

26 ibid s II.
} 
capacity building' ${ }^{27}$ covering industrial relations — guaranteeing freedom of association by grassroots labor unions independent of the Vietnam General Confederation of Labor (VGCL), which is the governmentcontrolled union, the right to strike, and collective bargaining-inspection mechanisms, and prevention of forced and child labor. The plan also contained provisions on transparency, government to government review mechanisms, technical assistance, and implementation. ${ }^{28}$

Again, one would expect these were all welcome developments for a labor chapter negotiation in a trade agreement. Unions in the US, however, deemed the labor consistency plans in TPP insufficiently robust. Their main criticism was that nothing guaranteed that these countries would in fact enforce those standards, except for promises to do so. Critics, such as the AFL-CIO, argued that the labor consistency plans were good on paper but failed to include quantifiable benchmarks or an independent evaluation of their compliance. ${ }^{29}$

In the case of Vietnam, critics pointed out that although the plan proscribed discrimination, it did not protect several important categories such as religion, political views, immigration status, and sexual orientation. ${ }^{30}$ Moreover, although the plan recognized many rights on freedom of association and against child labor and forced labor, it was unclear whether there would be penalties for employer violations and what those penalties would be. ${ }^{31}$

The most important concern was that given the considerably high commercial pressures to bring the treaty into force, these countries would gain market access in the US and all other TPP countries without having to make the new rights effective. Fulfillment of the obligations contained in the plan would thus be wholly discretionary and, if these countries faced no further pressure, it would be unlikely that they would comply. ${ }^{32}$

This view may seem too defeatist until one considers what has happened in previous agreements. The AFL-CIO noted that the experience with Colombia suggested the need for greater scrutiny from an independent evaluation:

Such pressure was brought to bear regarding the Colombia Labor Action Plan (LAP), which also contained positive objectives, but lacked benchmarking criteria or an independent evaluation mechanism. As a result, success was declared prematurely, and Colombia has been out of compliance with its labor obligations since Day One of the agreement. ${ }^{33}$

27 ibid s III.

28 ibid s IV, V, VI, VII, and VIII.

${ }^{29}$ AFL-CIO, 'A Gold Standard for Workers?' 4.

30 ibid 10.

31 ibid 11.

32 ibid 4.

33 ibid. 
According to the AFL-CIO, this premature certification has likely prevented the US from initiating labor consultations despite ongoing labor violations. The violence against workers and labor leaders in Colombia, including murder, was and continues to be a big concern. ${ }^{34}$ Based on this experience, critics argue, it would be hard to imagine that changes would be effective in Vietnam, Malaysia, and Brunei if the certification was subordinated to the pressures to conclude the agreement. ${ }^{35}$

The Colombian experience suggests that the greatest leverage for reform happens during negotiations and before an agreement is concluded. Critics of TPP saw it as a missed opportunity to push for effective reform, with parties settling instead for an agreement that sounded good but had a small chance of producing effective changes.

Despite these important criticisms, it is worth recognizing that the list of changes that Vietnam agreed to was quite extensive and amounted to a significant transformation of its labor law and industrial relations system. Even if the parties could have agreed to greater changes-as the AFL-CIO and the LAC wanted-or to stronger mechanisms for effective enforcement, the changes they were able to agree on should not be taken lightly. Vietnam, a one-party Communist country and officially a Socialist Republic, ${ }^{36}$ was willing to transform its collective bargaining system, one of the bastions of its highly-centralized regime through which the government exercises tight control. The agreement was, as it is often the case, a compromise and thus not ideal. But the Vietnamese government's wish to be part of TPP created a unique opportunity for the greatest labor reform in that country in recent history.

Consider these two important changes. First, the Vietnamese government agreed to lose the monopoly of the VGCL, the government-controlled union confederation to which currently all Vietnamese workers must belong. Under current law, if workers decide to strike without support of the VGCL leadership, the strike is considered illegal, as is often the case. ${ }^{37}$ Under the reforms agreed in the Vietnam consistency plan, workers would be allowed to form grassroots unions without previous authorization and independent of VGCL. ${ }^{38}$ This independence is further guaranteed by enabling grassroots unions to collect their own membership dues and to receive their union share of the $2 \%$ fee paid by employers. ${ }^{39}$ Moreover, workers may form unions across-enterprises or at sectoral and regional levels. ${ }^{40}$

\footnotetext{
${ }^{34}$ See US Department of Labor, 'United States-Colombia Trade Promotion Agreement: Public Report of Review of US Submission 2016-02 (Colombia)' (2016)

<https://www.dol.gov/sites/default/files/documents/ilab/PublicReportofReviewofUSSubmission201602_Final.pdf $>28-31$.

35 ibid 4.

36 See Socialist Republic of Viet Nam Government Portal, About Viet Nam <https://perma.cc/N6VB-93N3>.

${ }^{37}$ See Do Quynh Chi and Di van den Broek, 'Wildcat strikes: A catalyst for union reform in Vietnam?' (2013) 55 J Industrial Relations 5.

38 VLCP ss II.1 and II.2.

39 ibid ss II.B.1

40 ibid ss II.A.2
} 
Second, Vietnam agreed to let workers and labor unions 'request and receive technical assistance and training from any Vietnamese or international worker organization legally operating in Viet Nam'.41 This means that there could be significant involvement of international unions in helping Vietnamese workers form unions and monitoring implementation of reforms. ${ }^{42}$ As the AFL-CIO noted, there was a five-year grace period to implement the reform for allowing cross-enterprise or sectoral unionization, which was definitely not ideal, since the reform leverage of entering the TPP would be lost. This time lag, however, could be counterbalanced by effective monitoring of this obligation by the Vietnamese grassroots unions, the ILO, and even US NGOs, given that the reform allows international organizations to provide support and technical assistance.

After the failure of the original TPP, the Vietnamese government declared that it would continue with the reforms. ${ }^{43}$ An important incentive to continue with the labor law reform may be the proposed European Union-Vietnam Free Trade Agreement, which also contains a labor chapter, albeit less demanding than the TPP. ${ }^{44}$ After the original TPP was derailed, the scope of the labor reform in Vietnam was scaled back. For example, the term "freedom of association" was initially removed from the Labor Code amendment draft, although it was later reintroduced in the second draft. ${ }^{45}$ On 2 April 2017, the government released this second draft and opened them to public comments. ${ }^{46}$ This draft and government declarations suggest that independent unions are still contemplated in the new Labor Code although with important restrictions. ${ }^{47}$ Nevertheless, whether the reform happens, and particularly whether the government agrees to break the VGCL monopoly without US pressure remains to be seen. ${ }^{48}$

It should be noted that the plan included the creation of a Technical Assistant Program (TAP) in Vietnam by the ILO and a Labor Expert Committee (LEC). The TAP would provide support to 'facilitate the implementation of the legal and institutional reforms described in this Plan'. ${ }^{49}$ In addition, TAP would produce period reports with relevant data to assess implementation and make recommendations for improvement that Vietnam would need to heed to. ${ }^{50}$

\footnotetext{
41 ibid ss II.A.3(a). Italics added.

42 These organizations could include, for instance, the AFL-CIO Solidarity Center, which operates already in many other countries providing assistance and training.

43 Atsushi Tomiyama, 'Vietnam Remains Committed to TPP, Prime Minister Says' Nikkei Asian Review (Hanoi, 3 June 2017) < https://perma.cc/Y8EC-86VD>.

${ }^{44}$ See Press Release, European Commission, 'Free Trade Agreement between the European Union and the Socialist Republic of Vietnam' (1 February 2016) < https://perma.cc/2Q6F-PBER> ch 15.

45 Tran Thi Kieu Trang \& Richard A. Bales, On the Precipice: Prospects for Free Labor Unions in Vietnam, at 15 (https://papers.ssrn.com/sol3/papers.cfm?abstract id=3110721

${ }^{46}$ ILO in Vietnam, 'Draft Revised Labour Code Open for Comments' (Hanoi, 28 April 2017)

$<$ https://perma.cc/87BQ-2DV4>; although the consultation process was initially postponed, it has opened again. See ILO in Vietnam, 'Responding to Consultation on Labour Code Reform: Key points on gender and discrimination' (15 January 2018) <https://perma.cc/33EM-X285>.

47 ibid at $15-17$

48 See Vietnam: Move to Independent Labor Unions Stalls https://www.bna.com/vietnam-move-independentn73014462774/

49 VLCP ss V.B.2.

50 ibid.
} 
The LEC was to be integrated by three members with expertise in international labor law. ${ }^{51}$ The Chair would be designated by Vietnam and the US and would be an ILO representative or other independent individual. Each country would appoint a member, who could not be affiliated to their government. The LEC would also produce a report 'providing a factual review, including information and data' on the Plan's obligations, including Vietnam's implementation of the reforms and pointing to any concerns. ${ }^{52}$ The LEC would consider TAP reports in its reviews, as well as consider views from interested parties in Vietnam and the US. In addition, the Plan would be subject to consultations and the dispute settlement mechanism of the TPP labor chapter..$^{53}$

Beyond the supervisory mechanisms contained in the Plan, Vietnam is subject to the independent ILO reviews for the conventions it has ratified, ${ }^{54}$ which include conventions on non-discrimination ${ }^{55}$ and forced labor. ${ }^{56}$ Recently, Vietnam's Prime Minister has publicly declared the government's intention to ratify conventions on freedom of association and collective bargaining. ${ }^{57}$ Of course, whether Vietnam will ratify these conventions is uncertain, but if it does, it will have to report on implementation and compliance on these conventions to an ILO independent Committee. In addition, Vietnam is also a member of other conventions, such as the Convention on the Elimination of all Forms of Discrimination Against Women (CEDAW), which proscribes discrimination against women in the workplace and contains its own mechanisms for supervision and compliance. The Plan did not contain gender as a protected category of discrimination. CEDAW can perform a complementary function, making sure that this obligation, which Vietnam has agreed to in a convention different than TPP, could still be enforced. In short, these independent, ILO, and UN mechanisms could complement-and serve as important reference or pressure points - to the mechanisms in the consistency plan.

Thus, even though the Plan could have gone further in substantive rights, and ideally Vietnam's market access to the US wouldn't be granted until it had implemented these reforms, it was still a very significant step. It is important not to underestimate the magnitude of the promised reforms. Just consider whether the US government would agree to change its labor laws or collective bargaining system in a bilateral plan like the one agreed to by Vietnam. There are numerous accounts documenting violations of internationally recognized labor standards in the US and workers face plenty of obstacles-legal and

\footnotetext{
51 ibid.

52 ibid.

53 ibid s VII.

${ }^{54}$ Constitution of the International Labour Organisation (adopted 9 October 1946) 62 Stat 3485, 15 UNTS 35, art 22.

55 Discrimination (Employment and Occupation) Convention [ILO Convention No 111] (adopted 25 June 1958 ) 362 UNTS 31; Equal Remuneration Convention [ILO Convention No 100] (adopted 29 June 29 1951) 165 UNTS 303.

${ }^{56}$ Forced Labour Convention [ILO Convention No 29] (adopted 28 June 1930) 39 UNTS 55.

${ }^{57}$ Freedom of Association and Protection of the Right to Organise Convention [ILO Convention No 87] (adopted 9 July 1948) 68 UNTS 17; Right to Organize and Collective Bargaining Convention [ILO Convention No 98] (1 July 1949) 96 UNTS 257.
} 
illegal—to organize and bargain collectively. ${ }^{58}$ Debates about different aspects of labor reform in the US have been quite contentious and it is an area that governments often do not open up for reform very easily. Opening up for reform is even less common when the government in question is not democratic and sees labor organizing as a democratizing force that may pose a potential threat to its authority. So, limited as these changes are, they also need to be appreciated in this context.

Another important critique of the labor chapter was that it did not include a labor consistency plan for Mexico, a country with a worrisome record of labor standards violations. ${ }^{59}$ In a surprising turn of events, however, the Mexican government passed a constitutional reform addressing long-held concerns about its labor relations system, including dispute settlement, freedom of association, and collective bargaining. First, the reform proposed the elimination of the corporatist Conciliation and Arbitration Boards, formed by representatives of government, employers, and labor unions, that is in charge of settling labor disputes. These Boards have long been criticized for favoring the interests of employers and official unions. ${ }^{60}$ Instead, the reform proposed giving jurisdiction over labor disputes to courts, effectively shifting jurisdiction from the Executive to the Judiciary branch. Second, it also envisioned the creation of an independent, autonomous institute in charge of registering unions and of collective agreements. This institute, led by an independent director with recognized labor law expertise and established reputation, would replace the Ministry of Labor in performing these functions. Third, elections to determine requests for bargaining a collective agreement, contests for union leadership, and contests between unions over the ownership of a collective agreement must be free and secret. These are substantive reforms to the collective bargaining system that independent unions, scholars, and activists have demanded for years.

It seems that the TPP negotiation was a considerable factor for enacting a reform which this and previous governments had resisted. ${ }^{11}$ This unexpected reform, which went largely unnoticed in Mexico, shows how an international commitment, such as TPP, could be used to advance domestic reform even if the text of the agreement was not that effective at requiring those changes.

\footnotetext{
58 See Lance Compa, 'Unfair Advantage, Workers' Freedom of Association in the United States under International Human Rights Standards' (Human Rights Watch, August 2000) < https://perma.cc/6KJ4-9VCN>; Carol Pier, 'Discounting Rights Wal-Mart's Violation of US Workers' Right to Freedom of Association' (Human Rights Watch, 30 April 2007) <https://perma.cc/XXX7-6R9M>; Human Rights Watch, 'A Strange Case: Violations of Workers' Freedom of Association in the United States by European Multinational Corporations' (Human Rights Watch, 2 September 2010) <https://perma.cc/YK2B-GKVS>; Lance Compa, 'Human Rights and Workers' Rights in the United States' (AFL-CIO, 2006) <https://perma.cc/D563-UJ7G>; Jennifer Gordon, Suburban Sweatshops: The Fight for Immigrant Rights (Belknap Press 2007); Janice Fine and Jennifer Gordon, 'Strengthening Labor Standards Enforcement Through Partnerships with Workers' Organizations' (2010) 38 Politics \& Society 553.

59 AFL-CIO, 'A Gold Standard for Workers?' 7-9.

${ }^{60}$ See generally Graciela Bensusán, El Modelo Mexicano De Regulación Laboral (Plaza y Valdes, Mexico City 2000).

${ }^{61}$ See Arturo Alcalde, 'Una Inesperada e Histórica Reforma Laboral en México' in Reforma al Artículo 123 Constitucional 39, 39-74 (Tirant Lo Blanch, Mexico City 2017); Arturo Alcalde, Reforma Laboral, 'Una Historia Inesperada’ El Mundo del Abogado (Mexico City 4 November 2016) < https://perma.cc/28Q7-2TH7> Maquila Solidarity Network, 'Labour Justice Reform in Mexico' (2017) Briefing Paper <https://perma.cc/4QFZ-33SJ>; Alana Semuels, 'The TPP's Uneven Attempt at Labor Protection' The Atlantic (22 January 2016) < https://perma.cc/DL4D-PBFQ>.
} 
Since the withdrawal of the US and the failure of the original TPP, the domestic labor law reform in Mexico has taken a bad turn. The constitutional reform needs to be implemented in secondary legislation. However, the proposed legislation changes the constitutional reform in some important respects. For example, the proposed legislation now envisions that the autonomous institute in charge of registering unions be staffed in a tripartite fashion, including representatives of government, unions, and employers, following the corporatist model that the original reform was supposed to replace. Labor law analysts in Mexico have argued that the proposed legislative reform defeats the objectives of the constitutional reform and, if passed, would render it ineffective. ${ }^{62}$ It seems as if the US exit from TPP changed the incentives of the Mexican government. This reform, however, could be taken up now in the ongoing NAFTA renegotiation by independent unions, labor activists, and groups that support the original changes proposed. This demand may even be taken up by the US as a bargaining chip. So, perhaps NAFTA renegotiation might provide another opportunity to consolidate those labor reforms in the case of Mexico.

Considering the cases of Vietnam and Mexico, it seems that one lesson is, as argued by labor critics in the US, that the most leverage for reform is held during the negotiations of an agreement and before it enters into force. A second important lesson, however, is that the domestic reforms in Vietnam and Mexico seem to have nose-dived because the original TPP failed, not because it succeeded. So, there are important costs, at least when it comes to potentially beneficial domestic changes, of not concluding an agreement as well. Or, even in the case of CPTPP, of losing the considerable outside pressure of a powerful trading partner such as the United States. Perhaps a less understood consequence of the failure of the original TPP is the derailing of these significant domestic labor law reforms in Vietnam and Mexico. Now new opportunities arise for groups that want reform within each of these countries. Reform in Vietnam could be reignited by the free trade agreement negotiation with Europe. Reform in Mexico could go back to its original objectives as a result of CPTPP or, more likely, due to the NAFTA negotiations.

\section{Roadblocks ahead in enforcing labor standards}

In a recent decision, the only labor dispute to have been adjudicated in a trade agreement, the hurdles of enforcing labor standards have proven considerably taxing. In August 2011, the United States requested a Panel under the CAFTA-DR to address Guatemala's alleged failure to 'effectively enforce its labor laws, through a sustained or recurring course of action or inaction, in a manner affecting trade between the Parties.' ${ }^{3}$ In July 2017, after prolonged proceedings, the Panel sided with Guatemala on the

\footnotetext{
62 See Arturo Alcalde, 'Grotesca Iniciativa de Reforma Laboral' La Jornada (9 December 2017) $<$ https://perma.cc/SM8M-5C3D>.

63 Dominican Republic-Central America-United States Free Trade Agreement (adopted 5 August 2004) 43 ILM 514 [CAFTA-DR], art 16.2:1(a).
} 
two claims brought forth by the United States and concluded that Guatemala had not violated its commitments.

The panel held that even though Guatemala's law enforcement failures related to eight accounts of court-ordered reinstatements of employees dismissed for engaging in unionization and collective bargaining activities could, when looked at collectively, be characterized as a 'sustained or recurring course of action or inaction,' such failures had not affected trade between the Parties. According to the Panel, the failures taken together did not affect trade because the course of action or inaction, as so collectively construed, did not itself confer a competitive advantage on employers engaged in trade between the Parties, 'irrespective of the effects of individual failures.' ${ }^{64}$

Conversely, although the Panel did find one instance of a failure that affected trade (the case of the employees of Avandia), it could not hold Guatemala accountable, since this instance alone did not have a recurring nature. ${ }^{65}$ In the same vein, in relation to the Unites States' second claim, the Panel did not find Guatemala in violation of its labor FTA commitments, because the failure of its authorities to conduct proper inspections and impose penalties upon finding labor law violations was only proven in one instance (the case of the apparel manufacturer Fribo), the course of which was neither repeated nor prolonged. ${ }^{66}$

This decision, the first interpreting a labor chapter in a trade agreement, seems to confirm the skepticism of labor rights' advocates about the prospects of enforcing labor standards in a trade agreement, even if the text is now a central part of the treaty and there is a dispute settlement mechanism to review complaints.

\section{Beyond the Labor Chapter}

Concerning a treaty that was supposed to represent the 'gold-standard' of globalization, workers in the US felt left out. They were troubled, beyond the labor chapter, by the different standard of treatment, both in substantive rights and in enforcement, given to capital in the investment chapter. They saw TPP as advancing corporate interests but not those of labor. In their view, it was a far cry from 'goldstandard' often touted by the US government and other supporters.

But organized labor in the United States also were concerned about other areas of TPP including government procurement, rules of origin, and currency manipulation, where they believed TPP would not work to their advantage. These concerns made clear that labor advocates understood that competitive pressures on jobs and wages would come not only from the difference in labor standards between countries, or even the difference in overall labor costs. Competitive pressures could come instead from

\footnotetext{
${ }^{64}$ Arbitral Panel, In the Matter of Guatemala-Issues Relating to the Obligations Under Article 16.2.1(a) of the CAFTA-DR (14 June 2017) Final Report para $503<$ https://perma.cc/AA83-WATG>.

65 ibid para 504.

66 ibid paras 587-91.
} 
lower requirements on what counted as a regional product eligible for TPP benefits, the ability of other governments to make their exports cheaper by altering the exchange rate, or by the government's giving up the ability to favor domestic producers in government purchases. Thus, as it became clear with TPP, the agenda to make trade agreements more even-handed for domestic labor goes far beyond the labor chapter.

\section{A. Investment}

The most controversial of TPP chapters, Chapter 9 affords investors robust substantive rights and establishes a dispute settlement system that allows investors to sue states in transnational arbitration. ${ }^{67}$ This chapter gave rise to a heated debate in the United States. Critics derided it as an affront on domestic democracy and the rule of law ${ }^{68}$ and defenders saw it as a way to grant certainty and a non-political forum to investors should disputes arise. ${ }^{69}$ Surely critiques of the investor-state dispute settlement (ISDS) system had been raised before, including by academics and many developing country governments who bore the brunt of its effects. ${ }^{70}$ The US itself has been a promoter of and is a party to many agreements that contain ISDS, including NAFTA and a plethora of bilateral investment treaties (BITs). But these agreements had been signed by the US and other industrialized countries to advance the interests of their investors, often over the concern of real or imagined biased national courts in other countries. What was different this time was the realization that the US could be now the recipient of investment and thus its own courts could be bypassed..$^{71}$ This was also visible in strong European opposition to ISDS in the Trans-Atlantic Trade and Investment Partnership (TTIP) between the United States and Europe. ${ }^{72}$ In the case of TTIP, these concerns led to a proposal for a permanent court in charge of adjudicating investment disputes. ${ }^{73}$

${ }^{67}$ TPP, ch. 9.

${ }^{68}$ See Elizabeth Warren, 'The Trans-Pacific Partnership Clause Everyone Should Oppose' Washington Post (25 February 2015) <https://perma.cc/A3L8-QJ7J>; Letter from Law and Economics Professors to US Members of Congress (11 March 2015) <https://perma.cc/9XPT-R6ST>; Letter from Law and Economics Professors to US Members of Congress (7 September 2016) <https://perma.cc/4QUY-3XFV>.

${ }^{69}$ Letter from Professors and Scholars of International Law, Arbitration, and Dispute Settlement to US Members of Congress (20 April 2015) <https://perma.cc/HA2X-SS99>.

${ }^{70}$ Gus Van Harten, 'Who Has Benefited Financially from Investment Treaty Arbitration? An Evaluation of the Size and Wealth of Claimants' (2016) Osgoode Legal Studies Research Paper $135<$ https://perma.cc/2HXH-8FED>; David Schneiderman, Constitutionalizing Economic Globalization Investment Rules and Democracy's Promise (Cambridge Studies in Law and Society, Cambridge 2008); Sergio Puig and Anton Strezhnev, 'The David Effect and ISDS' (2017) 28 EJIL 731-61; Jason Yackee, 'Do Bilateral Investment Treaties Promote Foreign Direct Investment? Some Hints from Alternative Evidence' (2010) 51 VJIL 397.

${ }^{71}$ In Germany for example, Swedish energy company Vattenfall filled a request for arbitration against that state, following a democratic decision to phase out nuclear energy; see generally Vattenfall $A B$ and others $v$ Federal Republic of Germany, ICSID Case No ARB/12/12<https://perma.cc/3B6T-VEBU>.

${ }^{72}$ See European Commission, 'Online Public Consultation on Investment Protection and Investor-to-State Dispute Settlement (ISDS)' in the Transatlantic Trade and Investment Partnership Agreement (TTIP) (Report) (14 February 2015) <https://perma.cc/2D5H-M4BL> .

${ }^{73}$ Press Release, European Commission, 'EU Finalizes Proposal for Investment Protection and Court System for TTIP' (Brussels, 12 November 2015) < https://perma.cc/ZR7Q-FMSK>; see also Robert Howse, 'International Investment Law and Arbitration: A Conceptual Framework' (2017) IILJ Working Paper 2017/1 (MegaReg Series) $<$ https://perma.cc/36TX-6Q26>. 
Critiques of ISDS in the US were manifold. First, critics contended that there was no need for transnational arbitral panels bypassing US domestic courts. As public institutions, courts often had to balance difficult considerations in cases, taking into account the public interest. This would be particularly important, for instance, in cases involving health, safety, the environment, and even labor regulation. ${ }^{74}$ Arbitral panels, and panelists, were removed from the polity and did not have to consider the public interest, or even relevant precedents in US domestic law.

Second, investors' rights were defined too expansively, granting foreign investors greater rights than domestic investors in the United States. ${ }^{75}$ This amounted to discrimination against national investors. But it was also a source of concern for its implications to the regulatory capacity of the state. The protection afforded to foreign investors against state regulation, in the form of regulatory taking, was stronger than the one regularly provided by US constitutional law. The suits of the tobacco industry against state tobacco regulations both in developing and developed states had brought this regulatory restraint in high relief. ${ }^{76}$ These concerns were aired in TPP negotiations and, as a result, tobacco regulation was carved out from ISDS. Critics, however, saw this as confirmation that investor rights had encroached too much on state regulatory capacity in important areas and they needed to be adjusted.

According to labor advocates, the investment chapter promotes offshoring. By giving US corporations robust investment protections abroad, Chapter 9 creates incentives to move to countries with lower wages and labor costs, at considerable lower risks. ${ }^{77}$ At the same time, those rules disadvantage local companies, which will have to compete with exports coming from US companies, and others, based abroad. ${ }^{78}$ This makes local companies and thus local jobs more vulnerable to foreign competition.

As a host state, the US would be liable to complaints by foreign investors. Concerns include: 1) that the burden of proof does not require investors to demonstrate that a standard of protection under

\footnotetext{
${ }^{74}$ For a case involving minimum wage regulation, see generally Veolia Propreté $v$. Arab Republic of Egypt, ICSID Case No. ARB/12/15 < https://perma.cc/ZE2A-Q4KC>.

75 See Joseph Stiglitz, Beware of TPP's Investor-State Dispute Settlement Provision (2016) Roosevelt Institute TPP

Brief No $1<$ https://perma.cc/D8QN-BNXR>; Joseph Stiglitz, Why TPP Is a Bad Deal for America and American Workers (2016) Roosevelt Institute TPP Brief No $6<$ https://perma.cc/9HEG-RHGA $>$.

${ }^{76}$ See Philip Morris Brand Sàrl, Philip Morris Products S.A. and Abal Hermanos S.A. v. Oriental Republic of Uruguay, ICSID Case No ARB/10/7 <https://perma.cc/MV98-5YKD>; Philip Morris Asia Limited v. The Commonwealth of Australia (10 December 2013) PCA Case No 2012-12 <https://perma.cc/2QWB-PJ4T>; Robert K Stumberg and Deborah K Sy, 'TPPA and Tobacco Control: Threats to APEC Countries' (2014) 23 Tobacco Control 466-70; Robert K Stumberg, 'Safeguards for Tobacco Control: Options for the TPPA' (2013) 39 American J L \& Med 382-441. ${ }^{77}$ LAC and Public Citizen best articulate this argument. See LAC, 'Report on the Impacts of the Trans-Pacific Partnership' 59; see also Public Citizen, 'Initial Analysis of Key TPP Chapters' 1 (2015) < https://perma.cc/D8QN$\mathrm{BNXR}>$; this claim is in tension with an emerging literature challenging a causal relationship between the existence of investment treaties and foreign investment. See also United Nations Conference on Trade and Development [UNCTAD], Trade and Development Report 2014 (United Nations Publications, New York 2014) $<$ https://perma.cc/947F-C62Z> 159; If investment treaties are not promoting foreign investment flows in host countries, then the argument that they promote offshoring loses much of its force. Offshoring may still be incentivized by free trade agreements, such as TPP, but they may have to do with other incentives promoting market integration like tariff reduction, rules of origin, regulatory harmonization, government procurement, as well as tax incentives and geographic proximity.

${ }^{78}$ LAC, 'Report on the Impacts of the Trans-Pacific Partnership' 59.
} 
customary international law be based on state practice and opinio juris, not solely on opinions of previous investment panels; $;^{79}$ ) that the text does not prevent investors from invoking the most-favored nation (MFN) principle to assert rights provided by other investment agreements; 80 and 3) the expansion of ISDS to other areas such as financial services ${ }^{81}$ and intellectual property, ${ }^{82}$ which would make the US government more vulnerable to lawsuits.

Additionally, Chapter 9 contains text that has been challenged on public interest grounds. For instance, the 'investment' definition goes beyond real property. Under the US Constitution, 'regulatory takings' primarily applies to regulations affecting real property. ${ }^{83}$ Chapter 9 goes well beyond real property, making the government potentially liable for affecting a wide range of interests. Similarly, the definition of 'investor' creates a very low threshold, including parties that are 'attempting to make' an investment. Actions such as 'channeling resources or capital' or 'applying for a license' are considered valid 'attempts' to make an investment and are thus protected. ${ }^{84}$ Furthermore, substantive investor rights such as 'fair and equitable treatment' and 'indirect expropriation' that arbitral tribunals have interpreted expansively were incorporated in the text of Chapter 9.85

Critics also raised rule of law concerns, particularly about a systemic conflict of interest facing private arbitrators who routinely act as legal counsel for corporations or governments too. ${ }^{86}$ The system does not have accountability mechanisms to prevent 'miscarriages of justice' by arbitrators. ${ }^{87}$ During the TPP debate, Senator Elizabeth Warren raised many of these concerns. ${ }^{88}$ An additional concern, of special importance to the labor movement, raised by Senator Warren as well as economist Joseph Stiglitz, was that ISDS could enable corporations to challenge legitimate labor policy and laws in international tribunals. ${ }^{99}$ Although critiques of regulatory autonomy have focused on the environment, health, and safety, based on past investors' attempts—and often success—in challenging regulations in these areas, a

\footnotetext{
79 ibid 18.
}

80 ibid.

81 ibid; Public Citizen, 'Initial Analysis of Key TPP Chapters’ 13.

82 Public Citizen, 'Initial Analysis of Key TPP Chapters' 13; LAC, 'Report on the Impacts of the Trans-Pacific Partnership' 47 (observing that the safeguard contained in Article 9.15 preserving the ability of governments to protect public health or achieve other regulatory objectives safeguard is meaningless because that provision requires measures to be 'otherwise consistent with [Chapter 9]').

83 Public Citizen, 'Secret TPP Investment Chapter Unveiled: It's Worse than We Thought' (2015)

<https://perma.cc/S2BW-JBHX> 3, 5-6, 11; Public Citizen, 'Initial Analysis of Key TPP Chapters' 14.

${ }^{84}$ Pursuant to footnote 12 to Article 9.1; Public Citizen, 'Secret TPP Investment Chapter Unveiled: It's Worse than We Thought' 9.

85 Public Citizen, 'Initial Analysis of Key TPP Chapters' 12-14; Public Citizen, 'Secret TPP Investment Chapter Unveiled: It's Worse than We Thought' 5-6.

${ }^{86}$ Public Citizen, 'Initial Analysis of Key TPP Chapters' 13; Public Citizen 'Secret TPP Investment Chapter Unveiled: It's Worse than We Thought' 4-5.

${ }^{87}$ LAC, 'Report on the Impacts of the Trans-Pacific Partnership' 59.

88 Warren, 'The Trans-Pacific Partnership Clause Everyone Should Oppose'; for a response to Senator Warren's oped, see Jeffrey Zients, 'Cross Post: Investor-State Dispute Settlement (ISDS) Questions and Answers' The White House Blog (26 February 2015) < https://perma.cc/6KUV-BCJU>; see also 'Don't Buy the Trade Deal Alarmism’ Washington Post (Washington DC 11 March 2015) < https://perma.cc/DZ2D-WZ66>.

89 Warren, 'The Trans-Pacific Partnership Clause Everyone Should Oppose'; Stiglitz, Beware of TPP's Investor-State Dispute Settlement Provision; see also Stiglitz, 'Why TPP Is a Bad Deal for America and American Workers'. 
concern for labor regulation may be warranted. Either because an investor challenges labor regulation, such as a minimum wage law, ${ }^{90}$ that affects its interests or because a government measure to prevent job losses comes into conflict with investor interests. ${ }^{91}$

Finally, labor advocates also pointed out that the treatment of capital and labor in TPP could not be more dissimilar. Workers must petition their governments to file a claim arising from labor standards violations under Chapter 19. Thereafter, they must engage in lengthy and arduous campaigns to attempt to move cases through the process with no guarantee that the case would be taken by their government or that, once taken, it would move forward. In contrast, under Chapter 9, investors have a private right of action and they may bring a suit directly against a government for violations of investment provisions.

Imagine what would happen if workers, consumers, or environmentalists were given standing to challenge corporate action that violated rights recognized by TPP in arbitral panels. This is precisely what unions and some commentators have proposed:

Consider instead creating an innovative alternative system to enforce trade agreements' labor, environmental, and consumer-protection provisions. Let the same door open to investors wronged by governments swing open for workers and communities harmed by investors. Give civil-society forces the power to bring multinational corporations before a neutral arbitral panel to seek damages for violations of labor rights, environmental standards, consumer protections, and human rights that relevant chapters of the trade agreement purport to guarantee and protect. And to be credible, an arbitration panel in such proceeding should be drawn from experts in these social fields, not trade lawyers and economists. ${ }^{92}$

\footnotetext{
${ }^{90}$ In 2012, Véolia, a French multinational utility company instituted a dispute against Egypt under the 1974 EgyptFrance bilateral investment treaty. The claimant demanded USD \$110 million in damages following an increase in Egypt's minimum wage. Its claim arises out of a contract between Veolia's subsidiary, Onyx Alexandria, and the governorate of Alexandria to provide waste management services through which Egypt's allegedly gave assurances to maintain the minimum wage at a particular level. The proceedings are still pending, and the last hearing of the Tribunal on the merits took place in Paris on 9 February 2017. See also Veolia Propreté v. Egypt.

${ }^{91}$ In 2009, AbitibiBowater, an American company with investments in paper mills and power generating businesses notified Canada of its intent to seek damages of CAD $\$ 500$ million under NAFTA. AbitibiBowater was facing financial difficulties and was closing several mills resulting in the layoff of many foresters and mill workers. After the claimant closed its last active paper mill in Newfoundland, putting 800 employees out of work, the Newfoundland and Labrador passed the Abitibi-Consolidated Rights and Assets Act which, according to the claimant, cancelled AbitibiBowater's forestry and water rights in Newfoundland and Labrador and expropriated the company's hydroelectric generation facilities. The case was settled in 2010 for CAD \$130 million. AbitibiBowater Inc v Government of Canada (25 February 2010) Notice of Arbitration, ICSID Case No UNCT/10/1 <https://perma.cc/D3ZCPQKK >; for a record of how ISDS has threatened other public interest policies, see Public Citizen, 'Case Studies: Investor-State Attacks on Public Interest Policies Case Studies: Investor-State Attacks on the Public Interest' (2014) $<$ https://perma.cc/4XNF-UFH3>.

92 See Compa, 'How to Make the Trans-Pacific Partnership Work for Workers and Communities' Compa, 'NAFTA's Labor Side Agreement and International Labor Solidarity’.
} 
This would certainly change the balance of power of existing stakeholders in TPP. It is not to say that this would be the best or the only solution to the existing asymmetry between capital, labor, and other social groups. It is also possible to envision a reduction of investors' rights, both substantive and procedural, rather than a scaling up of the rights of other groups and the proliferation of arbitral panels bypassing national courts. Indeed, TPP negotiators carved out limitations on investors' rights for rules on tobacco products. A more general proposal in this direction may sound outlandish or politically impossible. But the very fact that it does should reveal how normalized this differential treatment of investment, compared to labor, has become. Any possible alternative would have to start from recognizing how law, and more specifically trade agreements like TPP, has helped to disadvantage the position of workers in the global market.

\section{B. Rules of origin}

Chapter 3 of TPP regulates rules of origin (ROO). ${ }^{93}$ These are the rules that determine whether a good qualifies as originating in one of the TPP countries and is thus eligible for TPP market access and other benefits. Production of goods in today's global economy is highly disaggregated. A good produced in a country may in turn incorporate inputs coming from many different countries. Rules of origin aim to ensure that a minimum percentage of national content is met for the good to be considered as originating from a given country. This prevents 'leakage', or the extension of preferential benefits to goods mostly produced in non-participating countries.

The main opposition to ROO in TPP came from the auto, auto parts, and light truck sectors. Unions and labor advocates considered ROO too permissive in the auto industry, allowing market access to products of non-TPP countries. These would benefit firms producing in countries that did not abide by the same labor and environmental standards as the US, getting a competitive edge and undermining US jobs. TPP lowered the $62.5 \%$ content requirement under NAFTA (already blamed for promoting offshoring to Mexico) to $45 \%$ regional value content. Critics contended that an auto with $55 \%$ Chinese, Filipino, or Thai content could thus be eligible for TPP tariffs, endangering production in the United States. ${ }^{94}$ Moreover, the threshold for many auto parts is as low as $35 \%$. In practice, low thresholds in parts lower the overall actual content requirement below the nominal $45 \%$ because a qualifying part is considered as $100 \%$ regional when calculating the total value of the vehicle, even if the part only met the lowest, $35 \%$ content standard. 95

Finally, critics contended that since TPP was open to other countries to join in the future, the regional value content standard would progressively harm the US auto industry. As more countries join or 'dock on' to the agreement, the $45 \%$ standard would erode the possibility that an auto, auto part, or light

\footnotetext{
93 TPP ch. 3.

94 Public Citizen, 'Initial Analysis of Key TPP Chapters' 18-19.

${ }^{95}$ LAC, 'Report on the Impacts of the Trans-Pacific Partnership' 55-56.
} 
truck is made by US workers, given that the regional content threshold could be met with products from more countries. ${ }^{96}$

Rules of origin in other industries such as textiles, however, seemed very favorable to US producers and to the detriment of other TPP countries. The three transformation or yarn forward rule, required that the yarn, the textile, and the final garment be produced in a TPP country to be considered as originating in the region. This seemed to disadvantage countries like Vietnam or Malaysia, who don't produce yarn and for whom having to import it from a TPP country would put its producers at a disadvantage. ${ }^{97}$

Thus, it seems that ROO will continue to be the source of contention as producers and workers in different sectors within each country push for regional origin thresholds that seem to favor them. Undoubtedly, as some scholars have pointed out, there is room for clarification and simplification of ROO. ${ }^{98}$ To the extent that there are unnecessary or unduly complex administrative procedures, simplification can eliminate transaction costs and help regional producers take advantage of the preferential regional tariff. But the greatest source of friction is likely to come from significant sectors in different countries, such as automobiles, who are often in competition between them and rightly worry about losing out. Just as in tariff negotiations, governments would need to make concessions in ROO and find ways to compensate when they estimate that a sector would be hit. Workers, from both developed and developing countries, are right to point out this area as one that deeply affects them and to make their government responsive to their concerns.

\section{Government procurement}

TPP's Chapter 15 on government procurement requires member states not to discriminate against foreign suppliers, or local suppliers with foreign affiliation or ownership, for government purchases. ${ }^{99}$ In other words, TPP members are required to treat providers of other TPP members as they treat their own national providers. This international obligation, present in the Government Procurement Agreement of

\footnotetext{
96 ibid.

${ }^{97}$ Kimberly Elliott, 'TPP Risks and TTIP Opportunities: Rules of Origin, Trade Diversion, and Developing Countries' (2016) Center for Global Development Policy Paper $078<$ https://perma.cc/6TA6-8NJ3>.

98 ibid 1

${ }^{9}$ TPP, art 15.4 ('1. With respect to any measure regarding covered procurement, each Party, including its procuring entities, shall accord immediately and unconditionally to the goods and services of any other Party and to the suppliers of any other Party, treatment no less favourable than the treatment that the Party, including its procuring entities, accords to: (a) domestic goods, services and suppliers; and [...] 2. With respect to any measure regarding covered procurement, no Party, including its procuring entities, shall: (a) treat a locally established supplier less favourably than another locally established supplier on the basis of degree of foreign affiliation or ownership; (b) discriminate against a locally established supplier on the basis that the good or service offered by that supplier for a particular procurement is a good or service of any other Party...').
} 
the $\mathrm{W}^{\prime} \mathrm{TO}^{100}$ and other trade agreements, is in tension with a system of national preference for government purchases crystalized in the Buy American Act of 1933.101

The Buy American Act requires the federal government to buy 'articles, materials, and supplies' made in the United States. ${ }^{102}$ Coverage is limited to the federal government so state and local governments do not have to favor domestic suppliers. It generally applies to goods (supplies and construction materials) and thus does not extend to services. ${ }^{103}$ Finally, the obligation to favor domestic producers does not cover products for use outside the United States or those below a minimum threshold (typically USD 3,500). 104 The obligation can be waived for reasons of public interest, availability, quality, and unreasonable costs, among others. ${ }^{105}$

Chapter 15 thus waives and makes the Buy American Act inoperable regarding other TPP member states. ${ }^{106}$ Unions criticized the government procurement obligation for two main reasons. First, government procurement preferences to domestic producers function as a job creation program while relinquishing them weakens the domestic labor market. ${ }^{107}$ Treating other countries on an equal footing directs tax payer money away from firms that create jobs in the US. It is important to note, however, that foreign firms can also create jobs in the US. Under Buy American, foreign firms can participate in procurement, as long as their products are considered to be made in the US. While unions and labor

100 The Agreement on Government Procurement was included in the World Trade Organization, as a plurilateral agreement that members can chose to enter, and which the US is a party to. (15 April 1994) LT/UR/A4/PLURI/2 art IV. The text of TPP follows closely the text of the Revised Agreement on Government Procurement (GPA/113) 30 March 2012. https://www.wto.org/english/docs_e/legal_e/rev-gpr-94_01_e.pdf

101 Act of March 3 1933, 47 Stat 1520 (codified as amended at 41 USC s 8301-8305).

102 See 41 USC ss 8302(a)(1) ('Only unmanufactured articles, materials, and supplies that have been mined or produced in the United States, and only manufactured articles, materials, and supplies that have been manufactured in the United States substantially all from articles, materials, or supplies mined, produced, or manufactured in the United States, shall be purchased for public use...'); see also 41 USC ss 8303(a)(1)-(2) ('Every contract for the construction, alteration, or repair of any public building or public work in the United States shall contain a provision that in the performance of the work the contractor, subcontractors, material men, or suppliers shall use only (1) unmanufactured articles, materials, and supplies that have been mined or produced in the United States and (2) manufactured articles, materials, and supplies that have been manufactured in the United States substantially all from articles, materials, or supplies mined, produced, or manufactured in the United States.'). An end product is deemed to have been produced in the US "substantially all" from components made in the US, if the cost of those articles, materials or supplies exceed $50 \%$ of the costs of all components. See Kate M Manuel, 'The Buy American ActPreferences for "Domestic" Supplies: In Brief' (2017) CRS Reports R43140 < https://perma.cc/T9EL-4QRX>. Pp. 3-4

${ }^{103}$ However, according to a Congressional Research Service report, "any 'supply' portions of a service contract could potentially be subject to the Buy American Act.” See Kate M Manuel, "The Buy American Act—Preferences for "Domestic" Supplies: In Brief' (2017) CRS Reports R43140 <https://perma.cc/T9EL-4QRX>. Page 3 FN15 104 See 48 CFR s 2.101 (defining micro-purchase threshold); see also 41 USC ss 8302(a)(2)(C) and 41 USC ss $8303(\mathrm{~b})(1)(\mathrm{C})$.

10548 CFR s 25.103 (exceptions for supply contracts); 48 CFR s 25.202 (exceptions for construction contracts). 106 The 1979 Trade Agreement Act authorizes a waiver of the application of any Government Procurement law or regulation, including the Buy American Act, to countries with which the US has a trade agreement. Kate M Manuel, 'The Buy American Act_-Preferences for "Domestic" Supplies: In Brief' (2017) CRS Reports R43140 $<$ https://perma.cc/T9EL-4QRX>. Page 9

${ }^{107}$ LAC, 'Report on the Impacts of the Trans-Pacific Partnership' 19. 
advocates recognize that US firms and jobs could benefit from procurement opportunities abroad, ${ }^{108}$ they contend that no clear evidence exists on this matter. ${ }^{109}$ At any rate the benefits are not symmetrical. According to some accounts, the US procurement market almost doubles the size of all other TPP parties combined. ${ }^{110}$ Moreover, the US already had procurement agreements with all TPP parties except for New Zealand, Vietnam, Malaysia, and Brunei, so new procurement opportunities for the United States seemed limited. ${ }^{111}$

Second, Buy American is an important fiscal stimulus policy, particularly in times of recession. Labor advocates argue that the government ought to be able to spend taxpayer dollars in a targeted way, focusing on preserving or creating US jobs. ${ }^{112}$ This rationale motivated the "Buy America" provision in the $\$ 900$ billion stimulus package in 2009 to address the financial crisis. In the end, however, pushback from pro-trade advocates and fears of a potential trade war led Congress to include a proviso in the final Act clarifying that it should not be interpreted to contravene US international trade obligations. ${ }^{113}$ Finally, unions were concerned with the progressive expansion of the procurement obligations. Article 15.24.2 directs parties to 'commence negotiations with a view to achieving expanded coverage, including subcentral coverage' within three years. ${ }^{114}$

Based on these concerns, both the AFL-CIO and LAC insisted that TPP carved out all procurement projects funded under 'Buy American' and similar laws funding 'fiscal measures to stimulate the economy' in response to a recession. ${ }^{115}$ They also suggested that TPP should provide enough policy space to ensure that measures promoting economic and social justice were TPP-consistent. In addition, procuring entities should be able to adopt specifications that require a supplier to comply with prevailing wage laws as well as 'living' wage laws. ${ }^{116}$ Finally, they urged adopting a positive list approach including only those sectors explicitly listed, that no sub-federal entities be included without their expressed consent, and that the goods and services covered under the existing FTAs not automatically form the basis of the US offer. ${ }^{117}$ These last three considerations were largely met by the final TPP text.

\footnotetext{
108 AFL-CIO, Testimony Regarding the Proposed United States_Trans-Pacific Partnership Trade Agreement before the United States Trade Representative (25 January 2010) <https://perma.cc/PDB5-7RJW>. 25.

${ }_{109}$ See Public Citizen, 'Initial Analysis of Key TPP Chapters' 18;

${ }^{110}$ See Public Citizen, 'TPP Government Procurement Negotiations: Buy American Policy Banned, a Net Loss for the US’ (2015) < https://perma.cc/5622-NGVQ>1-2.

111 ibid 2

112 Public Citizen, 'Initial Analysis of Key TPP Chapters' 18; LAC, 'Report on the Impacts of the Trans-Pacific Partnership' 58.

113 American Recovery and Reinvestment Act of 2009, 123 Stat 115 s 1605(d) ('This section shall be applied in a manner consistent with United States obligations under international agreements.')

$114 \mathrm{TPP}$, art 15.24. It is important to note that 'Buy America' provisions have been excluded from the TPP, and they have ordinarily been excluded from prior treaties to which the US is party. See USTR, 'TPP Made in America Chapter 15. Government Procurement Chapter Summary’ (2016) <https://perma.cc/H5LE-9VKZ> 3).

115 AFL-CIO, Testimony Regarding the Proposed United States-Trans-Pacific Partnership Trade Agreement before the United States Trade Representative (25 January 2010) <https://perma.cc/PDB5-7RJW>. 25; LAC, 'Report on the Impacts of the Trans-Pacific Partnership' 19.

116 LAC, Report 19

117 AFL-CIO Testimony 26.
} 
The economic rationale for opening up government procurement to foreign products is no different from that of the rest of the economy. There can be efficiency gains to the government from lower prices. This would ultimately translate into savings to society, which would have greater resources to spend elsewhere. The question is whether, as labor advocates argue, government procurement can be used strategically, as a drive for job creation and as a fiscal stimulus during economic downturns. This question is ultimately one of whether a government wants to preserve greater policy autonomy in this domain and whether it wants to use this policy tool as a way to promote domestic production and employment. In the best scenario, this may lead to dynamic efficiency, but it may also lead to less efficient outcomes that a government is willing to accept to promote the public interest or reduce social costs.

\section{Currency manipulation}

A country is deemed a currency manipulator when it 'artificially depresses the value'118 of its currency vis-à-vis others. This intentional policy affects the nominal exchange rate, set by the relative supply and demand for a currency in foreign exchange markets. ${ }^{119}$ But a country may influence the exchange rate, usually by buying 'foreign assets such as US treasuries to increase demand for the US dollar, which increases the value of the dollar relative to their own currency. ${ }^{120}$ This devalued exchange rate boosts the manipulator's exports, thereby increasing US imports and suppressing US exports.

Many analysts have argued that currency manipulation has deleterious effects on US jobs and in the US economy at large. Scott and Glass contend that "currency manipulation-fueled trade deficits have reduced US gross domestic product (GDP), eliminated millions of US jobs, driven down US wages, and propelled the outsourcing of US jobs to currency manipulators." ${ }^{21}$ Moreover, they argue that the US trade deficit with other TPP countries, largely caused by currency manipulation, has already cost the US millions of jobs: "In 2015, the US deficit with TPP countries translated into 2 million US jobs lost, more than half (1.1 million) of which were in manufacturing." 122

Bergsten and Gagnon sustain that of all the countries affected by currency manipulation, the US has been the country hardest hit, resulting in a trade deficit increase by USD 200 billion to USD 500 billion per year and the loss of 1 to 5 million jobs as a result. ${ }^{123}$ These studies propose to curb currency

\footnotetext{
118 Robert E Scott and Elizabeth Glass, 'Trans-Pacific Partnership, Currency Manipulation, Trade, and Jobs’ (2016) EPI Briefing Paper No $420<$ https://perma.cc/QZ6V-2FKC> 1. 119 ibid 3.

120 ibid.

121 ibid 1.

122 ibid.

123 See C Fred Bergsten and Joseph E Gagnon, 'Currency Manipulation, the US Economy, and the Global Economic Order’ (2012) PIIE Policy Brief No PB12-25 < https://perma.cc/NW3Y-LWGC>; see also C Fred Bergsten and Joseph E Gagnon, Currency Conflict and Trade Policy: A New Strategy for the United States (PIIE, 2017).
} 
manipulation from artificially inflating the trade deficit and ultimately destroying jobs. TPP presented an opportunity to operationalize this policy goal. ${ }^{124}$

A number of scholars, however, are more skeptical that currency manipulation is easy to distinguish from other, legitimate monetary policies that also affect the exchange rate. Stiglitz, for instance, argues that "the very concept of 'currency manipulation' itself is flawed: all governments take actions that directly or indirectly affect the exchange rate. Reckless budget deficits can lead to a weak currency; so can low interest rates." 125 Other scholars have raised doubts about using trade-related remedies and about the inclusion of currency manipulation in trade agreements. ${ }^{126}$ Frankel points out that trade-related mechanisms to curb currency manipulation could come back to bite the US if other countries were to challenge US monetary policies. ${ }^{127}$

In the end, TPP countries agreed to a pact on macroeconomic policy in 'The Joint Declaration of the Macroeconomic Policy Authorities of Trans-Pacific Partnership Countries.' ${ }^{28}$ The declaration confirms countries' obligation, under the International Monetary Fund's Articles of Agreement, to 'avoid manipulating exchange rates...to gain an unfair competitive advantage', 'to foster an exchange rate system that reflects underlying economic fundamentals', and 'to refrain from competitive devaluation.' ${ }^{29}$ Countries also agreed to transparency and reporting commitments that require them to disclose publicly and periodically their macroeconomic data, including foreign exchange policies and assessments. ${ }^{130}$ Finally, countries agreed to meet periodically for macroeconomic policy consultations. ${ }^{131}$

Some analysts argued the unwillingness of the US government to include currency manipulation disciplines in TPP made the agreement a 'fatally flawed trade and investment deal.' ${ }^{132}$ Others considered TPP's side accord on currency manipulation as an important step forward, providing guidelines that could help deter currency intervention in the future. They highlighted that TPP was the first ever trade agreement to include a declaration on 'macroeconomic policy and exchange rates' ${ }^{133}$ and that while the side agreement was not enforceable:

\footnotetext{
124 See Simon Johnson, 'How to Fight Currency Manipulation’ Project Syndicate (24 March 2015) $<$ https://perma.cc/AE76-R5L9> ('Currency manipulation is a real problem that causes significant damage. The TPP deal-if it establishes a dispute-resolution mechanism that can quickly dismiss frivolous claims and home in on genuine cases - may offer the best chance to fix it.').

125 Joseph Stiglitz, 'A Trade War with China isn't Worth it' The Guardian (7 April 2010) < https://perma.cc/SJ8N6238>.

${ }^{126}$ See Dani Rodrik, 'Should the US Respond to China’s Exchange Rate Policy by Raising its Import Tariffs?' Dani Rodrik's Weblog (14 June 2007) <https://perma.cc/HKC8-9WXW>.

${ }^{127}$ Jeffrey Frankel, 'The Top Ten Reasons Why Trade Agreements Should Not Cover Currency Manipulation' Econbrowser (12 June 2015) <https://perma.cc/27DQ-AWL9>.

128 Joint Declaration of the Macroeconomic Policy Authorities of Trans-Pacific Partnership Countries (5 Nov 2015)

$<$ https://perma.cc/H3CY-2MAX $>$.

129 ibid 1.

130 ibid 2.

131 ibid 2-3.

132 Scott and Glass, 'Trans-Pacific Partnership, Currency Manipulation, Trade, and Jobs' 13.

${ }^{133}$ C Fred Bergsten and Jeffrey J Schott, 'TPP and Exchange Rates' PIIE Trade \& Investment Policy Watch (6 November 2015) <https://perma.cc/67NX-28GB>.
} 
the commitments in the declaration are far-reaching in ruling out competitive devaluations and persistent exchange rate misalignments. In addition, the requirements for more transparency and public disclosure of data on exchange rate policies, including currency intervention, should make the 'naming and shaming' of manipulators more effective. ${ }^{134}$

The labor movement had asked the US government to include 'enforceable currency rules subject to trade sanctions in the text of the agreement.' 135 Instead, they argued, TPP included a side agreement with guidelines, not subject to trade sanctions and thus unenforceable. ${ }^{136}$ Labor advocates argued that currency manipulation by other countries, which decreases the value of their currencies vis-à-vis the US dollar, makes those countries' exports cheaper and displaces American workers. They claim that millions of American jobs have been lost to currency manipulation. ${ }^{137}$ Moreover, they pointed out that three TPP countries have been listed as 'egregious' currency manipulators, namely Japan, Malaysia, and Singapore. 138 The US auto industry seemed particularly concerned about the effects of currency devaluation on price advantages for foreign cars and its long-term effects on jobs. ${ }^{139}$ That is why labor advocates considered it necessary to establish strong disciplines to curb currency intervention and saw failure to include effective mechanisms in TPP as a reason to reject the treaty. The Joint Declaration was supposed to enter into force with the original TPP but it is not mentioned in the CPTPP. Thus, an agreement on currency manipulation is likely to be off the table in the revised treaty without the US.

As it can be gleaned from this debate, it is unclear that including rules of currency manipulation in a trade agreement would be necessarily desirable. If effective, they could impose important restrictions in monetary policy autonomy from which the US would not be exempt. What is clear, however, is that this area of domestic policy has come under greater scrutiny and that, again, labor advocates in the US have rightly pointed out that it has an effect on workers and their ability to compete.

\section{The Pains from Trade and Domestic Compensatory Mechanisms}

The other face of gains from trade is loss: loss of jobs and wage decline. This should not come as a surprise since it is predicted by the theory of comparative advantage and assumed as one of the results of specialization and trade. ${ }^{140}$ The expectation is, of course, that the overall gains from specialization and

\footnotetext{
134 ibid.

135 LAC, 'Report on the Impacts of the Trans-Pacific Partnership' 14.

136 ibid.

137 ibid 43.

138 ibid 44, referring to the Peterson Institute List and citing to Joseph E Gagnon, 'Combating Widespread Currency

Manipulation' (2012) PIIE Policy Brief No PB12-19<https://perma.cc/T2WG-TMN2>.

139 ibid 43-44.

140 Rodrik, The Globalization Paradox 50-61.
} 
trade, in the form of greater production and consumption capabilities, will outweigh the overall costs to society. It is expected that a country will have domestic compensatory mechanisms in place to compensate those who have lost so that the welfare gains can be shared. However, the trade-specific adjustment mechanism has proven inadequate and the broader societal mechanisms for redistribution have been weakened, not strengthened, as trade liberalization deepened. ${ }^{141}$

Established by President Kennedy, the Trade Adjustment Assistance (TAA) program sought to support workers and firms affected by imports. ${ }^{142}$ Since then, the funding for this program has ebbed and flowed depending on the administration. ${ }^{143}$ To qualify, workers must demonstrate that import competition has 'contributed importantly' to their job loss or that their job has been outsourced to production abroad. Although eligibility criteria was initially narrow and required showing harm from a tariff cut, it has broadened over time allowing claims from workers who lost their jobs in industries directly related to the goods displaced by imported products. Components of the program include unemployment insurance, income support, health insurance, retraining programs, and relocation allowances. ${ }^{144}$

TAA has stirred debate along partisan lines. Conservatives typically deride it as wasteful and inefficient while liberals consider it largely insufficient. ${ }^{145}$ During the debate about TPP, Democrats in Congress tried to stop the renewal of the fast-track or trade promotion authority, which gives the President authority to negotiate a trade agreement subject to an up or down vote in Congress, without the possibility of amendments. To stop approval of fast-track authority, Democrats voted to reject TAA, a program they usually support. ${ }^{146}$ Such was the opposition TPP elicited. In the end, Congress finally renewed the trade promotion authority and the trade adjustment assistance programs were reinstated. ${ }^{147}$

In a paper about the labor market effects from trading with China, economists Autor, Dorn, and Gordon analyze employment and wage effects in areas affected by imports in varying degrees, as well as how these effects relate, in turn, to uptake in government transfers. ${ }^{148}$ They find that TAA is practically insignificant compared to other transfer programs.

\footnotetext{
${ }^{141}$ See Joseph E Stiglitz, Globalization and Its Discontents Revisited: Anti-Globalization in the Era of Trump (Norton, New York 2017) 8-20.

142 Trade Expansion Act of 1962, Pub L No 87-794, 76 Stat 877 (1962) title II, s 232.

${ }^{143}$ For a history of the program since its creation, see Edward Alden, Failure to Adjust: How Americans Got Left Bebind in the Global Economy (Rowman \& Littlefield, New York 2016) 110-26; for a detailed legislative history of the program, see Benjamin Collins, 'Trade Adjustment Assistance for Workers and the TAA Reauthorization Act of 2015’ (2016) CRS Report R44153 < https://perma.cc/5LWF-PBGY> 11-12.

14419 USC s 2271-2331 (for workers); 19 USC s 2341-2356 (for firms); 19 USC s 2371-2373 (for communities); 19 USC s 2401-2401g (for farmers).

145 Nick Timiraos, '5 Questions on Trade Adjustment Assistance’ W all Street Journal Blog (15 June 2015) $<$ https://perma.cc/G45E-VDZD>.

146 ibid.

147 Trade Adjustment Assistance Reauthorization Act of 2015, Pub L No 114-27, 129 Stat 374 (2015) Title IV, ss 402(b), (c), 403(c).

${ }^{148}$ David H Autor, David Dorn and Gordon H Hanson, 'The China Shock: Learning from Labor-Market Adjustment to Large Changes in 'Trade' (2016) 8 Annual Rev Econ 205.
} 
TAA, the primary federal government program intended to help workers who lose their jobs as a result of foreign competition is effectively inconsequential in local adjustment to trade shocks. Workers eligible for TAA receive extended unemployment benefits of up to 18 months, as long as they remain enrolled in a training program, and may obtain allowances toward relocation, job search, and healthcare. Trade-exposed CZs [commuting zones] certainly experience sharp relative growth in per capita receipts of TAA benefits. However, although TAA reacts elastically to trade exposure, it is far from the transfer category that responds most strongly in terms of dollar expenditure; the total volume of TAA spending is negligible relative to many other transfer programs. ${ }^{149}$

In addition, other programs such as medical benefits, federal income support, and Social Security retirement and disability benefits are much more sensitive to trade exposure, with spending growing in areas with higher exposure to imports. ${ }^{150}$ Even when, overall, these transfer programs respond to local import exposure, Autor et al. conclude that their compensatory effect seems to be very limited:

Despite the responsiveness of local transfer payments to local import exposure, on the whole there appears to be limited regional redistribution of trade gains from winners to losers. Comparing again the residents of CZs [commuting zones] at the 75th and 25th percentile of import exposure, those in the more exposed location experience a reduction in annual household wage and salary income per adult of $\$ 549$, whereas per capita transfer income rises by approximately $\$ 58$, thereby offsetting just a small portion of the earnings loss $\ldots{ }^{151}$

The US spends too little in adjustment, not only judged by the program's negligible effects, but also when compared to other industrialized countries:

The United States spends just 0.1 percent of GDP on 'active labor market policies' those designed to move the unemployed back into better jobs-which is seven times less than the average Organization for Economic Cooperation and Development (OECD) country. The OECD has found that most European countries, as well as Canada and Australia, have training systems that are 'more comprehensive and stable' than those in the United States. ${ }^{152}$

\footnotetext{
149 Autor, Dorn and Hanson, 'The China Shock' 231. References omitted.

150 ibid.

151 ibid.

152 Alden, Failure to Adjust 125.
} 
Denmark spends more than $2 \%$ of GDP, or twenty times more than the U.S, in helping its unemployed workers go back to work. ${ }^{153}$ Being one of the most open economies in the world, the US spends the least of any other advanced economy in helping its workers adjust to the losses brought by trade openness. ${ }^{154}$ It is thus not surprising that communities who have experienced these long-lasting trade effects, where adjustment benefits have not adequately helped workers find new jobs or recover their income, oppose new trade agreements such as TPP.

TAA has been insufficient to address losses brought about from trade liberalization. ${ }^{155}$ Alden recounts C Fred Bergsten's stark disjunctive for US policy, back in the 1970s, to address the losses and dislocation of workers and firms resulting from competing imports: the US could either limit imports, through tariffs, or it could take advantage of the gains from trade and help losing workers and firms to adjust. ${ }^{156}$ Unfortunately, Alden concludes, the US followed a third option. It pursued trade liberalization but did not establish the necessary compensatory mechanisms. ${ }^{157}$

The failure to help American workers adjust to the new scale and intensity of global competition is one of the bigger mistakes of US government economic policy in the last half century, one that has resulted in an enormous waste of human capacity and in eroding popular support for international trade and US engagement with the world. While many other countries have overhauled, refined, and expanded their labor market adjustment schemes, the basic structure of US federal programs remains unchanged since the creation of unemployment insurance (UI) in 1935 as part of the New Deal. ${ }^{158}$

Analyses of the effects of TAA show not only that resources were insufficient, but also that they were not well targeted. They recommend structuring the benefits to incentivize retraining, including on the job-training, and help workers find new jobs, as opposed to helping them slide out of the workforce. ${ }^{159}$ At a moment when there is so much discontent about trade in the US, rethinking trade policy should include not only changes in the rules of trade agreements but also a considerable transformation of adjustment policies. Such reform could help to make adjustment meaningful and trade policy more palatable. It could help achieve the promise that trade gains will outweigh the losses.

\footnotetext{
153 ibid 114.

154 ibid 144.

155 ibid 126.

156 ibid 107.

157 ibid 126.

158 ibid 113.

159 ibid 115 and 125.
} 


\section{Conclusion}

One comes out of this debate with a sense that both proponents and critics of the TPP labor chapter are partly right. Proponents of TPP were right to point out that TPP is the trade agreement that includes the most advanced labor provisions. In the traditional way of thinking about trade and labor linkage, it is the gold standard. Critics were right, however, to point out that TPP falls considerably short in addressing the concerns of labor. TPP represents the continuation of a model of trade agreements, perhaps the gold standard of that liberal globalization model, that labor groups deem as partly responsible for their troubles. The question therefore should be not whether TPP does more than previous trade agreements, but whether it can address, more effectively and perhaps more imaginatively, the concerns that labor groups have raised for quite some time and that have taken renewed urgency in the current political moment.

The failure of the original TPP in the US should be an opportunity to think anew the legal architecture of globalization, as structured by trade agreements, and the domestic policies that need to be in place to make globalization work. The most important opposition to TPP came from the United States because of concerns of job losses, wage decline, income distribution, and reduced policy autonomy. The opposition of labor groups in the US to what was in fact the most advanced labor chapter in a trade agreement, should make clear that labor standards are just one among many aspects of trade agreements that affect jobs and conditions of work. The concerns of labor groups in the areas of investment, rules of origin, currency manipulation, and government procurement make evident that there are other areas of trade agreements that may turn to be just as important in managing the effects of trade on labor.

Moreover, the history of enforcement of labor standards in trade agreements has left much to be desired, and even more so when compared to the treatment of investment. This asymmetry of treatment, in terms of standing to bring complaints, availability of remedies, and celerity of dispute settlement, reflects an unbalanced order that has weakened workers. The current moment offers an opportunity to think how to rebalance trade agreements with the interests of jobs, wages, and working conditions at the center.

A significant, but less noticed, achievement of the original TPP was the domestic labor reforms it set in motion in Vietnam and Mexico through a labor side agreements and US pressure respectively. These were reforms that had long been resisted by the governments of these countries and that would have been unthinkable without the TPP negotiation process. This would suggest that the domestic changes before a trade agreement enters into force may be more important than the ultimate design of the labor chapter. Unfortunately, the failure of the original TPP has stymied or derailed these reforms making it clear that not concluding the TPP also had costs for workers and labor groups.

All this is not to say that labor chapters are unimportant. They need, however, to be effective to be credible and have an impact. Labor groups in developing countries could make greater use the 
negotiations of labor chapters in trade agreements as leverage to improve conditions of work and to ensure freedom of association and collective bargaining in contexts where there is often a stultifying, government-controlled union movement. But developing countries could also take advantage of this moment to think more broadly about the form of globalization they want to promote and how they may be able to better reap its benefits.

The debate about TPP and labor in the US also made clear that the (expected) losses created by international trade have not been properly addressed through domestic compensatory mechanisms. It will be hard to revert current opposition to trade without a serious reform in the social insurance mechanisms that enable workers who lose their jobs or see their wages decline to adapt and get back on their feet. If TPP represented the "gold standard" of liberal globalization, that standard has been, as it was once for the monetary system, abandoned. An alternative form of globalization, capable of resisting a nationalist retrenchment, would have to take seriously the concerns of workers. It would have to rewrite the rules of international agreements to rebalance the treatment between capital and labor and to encourage robust safety nets at the domestic level. The revival of TPP in the form of CPTTP, unfortunately, so far seems to charge ahead without charting a new path. 